Supporting Information for:

\title{
Structure of an NADH-insensitive hexameric citrate synthase that resists acid inactivation
}

Julie A. Francois, Courtney M. Starks, Sasitorn Sivanuntakorn, Hong Jiang, Aaron E. Ransome, JeongWon Nam, Charles Z. Constantine, and T. Joseph Kappock*

Department of Chemistry, Washington University in St. Louis, St. Louis, MO 63130-4899 


\section{EXPERIMENTAL PROCEDURES}

Materials. Unless otherwise noted, all chemicals were obtained from Sigma or Fisher in the highest purity available. The trilithium salt of AcCoA was from ICN Biochemicals. CitCoA was the generous gift of Dr. Linda Kurz. IDA was charged with $\mathrm{NiSO}_{4}$ as recommended (Sigma). Blue Sepharose 6 FF was from Amersham Biosciences, DE-52 was from Whatman, Sephadex G25 and DEAE Sepharose were from Pharmacia, Bio-Rex was from Bio-Rad. A dye-ligand column kit (Cibacron Blue 3GA, Reactive Blue 4, Reactive Brown 10, Reactive Green 19, Reactive Red 120, and Reactive Yellow 86) was from Sigma. PCS was from Sigma. Chitin beads, pTwin1 plasmid, restriction enzymes, DNA modifying enzymes, and DNA size standards were from New England Biolabs. ODNs were obtained from IDT (Coralville, IA). Standard molecular biology methods $(1,2)$ were used except where noted. Gel filtration standards were obtained from BioRad. Proteins were concentrated using either YM10 or PM30 membranes in an Amicon ultrafiltration device, or an Amicon Ultra centrifugal filter device (15 mL, 30,000 MWCO).

Analytical procedures. For ESI-MS, each form of AaCS (33 - $100 \mu \mathrm{g})$ was loaded onto an in-line C18 guard column (MS Scientific) and infused into Micromass QTOF Ultima quadrupole MS with acetonitrile:water:trifluoroacetic acid (80:20:0.1). The accelerating potential was $10 \mathrm{eV}$. The expected mass accuracy was \pm 3 Da.

Protein concentrations were measured using the Bradford assay (Bio-Rad) with bovine serum albumin as a standard (3).

CD data were obtained on a Jasco J-500A spectropolarimeter as described (4). Melting temperatures $\left(T_{\mathrm{m}}\right)$ were determined with an estimated uncertainty of $\pm 0.2^{\circ} \mathrm{C}$.

Synthesis of dethiaAcCoA and CMX. DethiaAcCoA and CMX were synthesized by procedures developed by Drueckhammer and coworkers $(5,6)$, modified as described below. The compounds were analyzed by HPLC on a Waters 2487 dual wavelength absorbance detector monitoring 215 and $260 \mathrm{~nm}$ with a Waters XTerra MS C18 column (4.6 x $50 \mathrm{~mm}, 3.5 \mu \mathrm{m})$. Solvents used were aqueous potassium phosphate, monobasic (solvent A: $15 \mathrm{mM}$ ) and methanol (solvent B). Compounds were eluted at a flow rate of $0.5 \mathrm{~mL} / \mathrm{min}$ with $5 \%$ solvent $\mathrm{B}$ for $2 \mathrm{~min}$, followed by a linear gradient to $80 \%$ solvent B over 12 min, and then maintenance at $80 \%$ solvent B for 6 min. For all enzymes used in the synthesis, a unit (U) is defined as one $\mu \mathrm{mol}$ product formed per min. Expression and purification of the CoaA gene encoding pantotheinate kinase (PanK) is described below. Expression vectors pESC106 and pESC124, for phosphopantetheine adenylyltransferase (CoaD) and dephospho-CoA kinase (CoaE) respectively, were 
obtained from Erick Strauss and used to purify enzymes as described (7). Histidine-tagged PanK (H6PanK, wild type or R175H mutant) batches had specific activity of 4 - $5 \mathrm{U} / \mathrm{mg}$. Enzyme specific activities for CoaD and several batches of CoaE were determined by Linda Kurz and Marian Riley. CoaD had specific activity 3.3 - 3.6 U/mg. The batch of CoaE used for CoA analogue synthesis had activity 0.56 U/mg; several CoaE batches had no detectable activity.

Pantotheinate kinase (H6PanK). E. coli DH5 $\alpha$ gDNA was prepared using DNAzol (Molecular Research Center, Cincinnati $\mathrm{OH})$. A PCR product containing the CoaA gene was obtained $\left(55^{\circ} \mathrm{C}\right.$ annealing) with Taq DNA polymerase and ODNs 844 and 845 as primers and cloned in pDrive (Qiagen). The resulting plasmid was digested with NdeI and EcoRI and cloned into pET28a to give plasmid pJK220, which fuses PanK to a twenty amino acid N-terminal appendage containing a hexahistidine sequence. DNA sequencing revealed a G524 to A mutation that encodes an Arg175 to His mutation in PanK.

BL21(DE3) cells transformed with pJK220 were grown in LB supplemented with $70 \mathrm{mg} / \mathrm{L}$ kanamycin to $A_{600}=0.5-0.6$, at which point IPTG was added to a final concentration of $1 \mathrm{mM}$. After a further $4 \mathrm{~h}$ at $37^{\circ} \mathrm{C}$, cells were harvested by centrifugation $(15 \mathrm{~min}$ at $10,000 \mathrm{x} \mathrm{g})$ and stored at $-80{ }^{\circ} \mathrm{C}$. A modified literature procedure (8) was used to isolate H6PanK. All subsquent steps were performed at $4{ }^{\circ} \mathrm{C}$. Cells (typically $14 \mathrm{~g}$ ) were resuspended in buffer TS $(20 \mathrm{mM}$ Tris $\bullet \mathrm{HCl}, \mathrm{pH} 7.8$, and $0.5 \mathrm{M} \mathrm{NaCl})$ at $10 \mathrm{~mL}$ per g cells and disrupted by five cycles of sonication. Debris was removed by centrifugation (30 min at 35,000 $\mathrm{x}$ g) and the supernatant was adjusted to $30 \%$ saturation by the addition of solid ammonium sulfate over 15 min. After an additional $30 \mathrm{~min}$ stirring, solids were removed by centrifugation (20 min at 10,000 x g) and the supernatant was adjusted to $65 \%$ saturation by the addition of solid ammonium sulfate over 30 min. After an additional 30 min stirring, solids were collected by centrifugation (20 min at 10,000 x g) and redissolved in a minimal volume of buffer TS plus $5 \mathrm{mM}$ imidazole (typically $6 \mathrm{~mL}$ ). The protein solution was applied to an IDA-Ni ${ }^{2+}$ column $(2.5 \times 1.8 \mathrm{~cm})$ equilibrated in the same buffer. The column was washed with buffer TS $+5 \mathrm{mM}$ imidazole $(100 \mathrm{~mL})$, and then proteins were eluted with buffer TS + 300 $\mathrm{mM}$ imidazole while collecting fractions. Bradford dye-reactive fractions $(39 \mathrm{~mL})$ were pooled, concentrated using a Centriprep YM-10 ultrafiltration device, and exchanged into buffer TS containing 5\% $(v / v)$ glycerol. Following overnight dialysis against $20 \mathrm{mM}$ Tris $\bullet \mathrm{HCl}, \mathrm{pH}$ 7.8, $1 \mathrm{mM}$ EDTA, $1 \mathrm{mM}$ DTT, and $50 \%(v / v)$ glycerol, aliquots were frozen at $-80{ }^{\circ} \mathrm{C}$.

Activities were measured using a coupled assay (6). A volume of $0.8 \mathrm{~mL}$ contained $50 \mathrm{mM}$ Tris $\bullet \mathrm{Cl}, \mathrm{pH}$ 8.0, $20 \mathrm{mM} \mathrm{KCl}, 5 \mathrm{mM} \mathrm{MgCl}_{2}, 0.3 \mathrm{mM} \mathrm{NADH}, 0.4 \mathrm{mM}$ phosphoenolpyruvate, $5 \mathrm{U}$ lactate 
dehydrogenase, $5 \mathrm{U}$ pyruvate kinase, $5 \mathrm{mM}$ ATP, and variable amounts of H6PanK. After 3 min equilibration at $25^{\circ} \mathrm{C}$, the reaction was initiated by the addition of pantothenate to $1 \mathrm{mM}$, giving $0.81 \mathrm{~mL}$ final volume. The change in absorbance at $340 \mathrm{~nm}\left(\Delta \varepsilon=6220 \mathrm{M}^{-1} \mathrm{~cm}^{-1}\right)$ was monitored, and activities were determined from the slope of the line at $1-2 \mathrm{~min}$ after reaction initiation.

Dethiaacetyl-coenzyme A (dethiaAcCoA). A Bio-Rex 40 resin column was used to remove unreacted 5amino-2,2-dimethoxypentane following the nucleotide thioester aminolysis step (5). Crude dethiaAcCoA (100 $\mathrm{mL}$ of a $4 \mathrm{mM}$ aqueous solution) was applied to a DEAE Sepharose Fast Flow column $(2.5$ x $25 \mathrm{~cm})$, which was developed with a linear gradient of $\mathrm{LiCl}(0-0.15 \mathrm{M}, 1$ x $1 \mathrm{~L})$ in $3 \mathrm{mM} \mathrm{HCl}$. DethiaAcCoA eluted between $0.06-0.09 \mathrm{M} \mathrm{LiCl}$. After diafiltration to remove the inorganic salts, and lyophilization, dethiaAcCoA was obtained as a white solid (total yield 13\%). Analytical HPLC: $\mathrm{t}_{\mathrm{R}}=7.1 \mathrm{~min}, \lambda_{\max }=260$ nm. ${ }^{1} \mathrm{H}$ NMR (as lithium salt, $500 \mathrm{MHz}, \mathrm{D}_{2} \mathrm{O}$ ): 0.73 (s, 3H), 0.86 (s, 3H), 1.68 (quintet, $2 \mathrm{H}, J=6.5 \mathrm{~Hz}$ ), $2.17(\mathrm{~s}, 3 \mathrm{H}), 2.43(\mathrm{t}, 2 \mathrm{H}, J=6.0 \mathrm{~Hz}), 2.54(\mathrm{t}, 2 \mathrm{H}, J=7.3 \mathrm{~Hz}), 3.10(\mathrm{t}, 2 \mathrm{H}, J=6.8 \mathrm{~Hz}), 3.42-3.48(\mathrm{~m}, 2 \mathrm{H})$, $3.54(\mathrm{dd}, 1 \mathrm{H}, J=5.0 \mathrm{~Hz}, 9.5 \mathrm{~Hz}), 3.81(\mathrm{dd}, 1 \mathrm{H}, J=4.8 \mathrm{~Hz}, 9.3 \mathrm{~Hz}), 4.00(\mathrm{~s}, 1 \mathrm{H}), 4.22$ (br, $2 \mathrm{H}), 4.57$ (br, $1 \mathrm{H}), 6.17(\mathrm{~d}, 1 \mathrm{H}, J=7.5 \mathrm{~Hz}), 8.27(\mathrm{~s}, 1 \mathrm{H}), 8.55(\mathrm{~s}, 1 \mathrm{H})$. HRMS (ESI): [M-H] calcd for $\mathrm{C}_{24} \mathrm{H}_{40} \mathrm{~N}_{7} \mathrm{O}_{17} \mathrm{P}_{3}$ $m / z$ 790.1616, found 790.1637; first isotope mass of [M-H] calcd 791.1650, found 791.1675. DethiaAcCoA was quantitated by absorbance spectroscopy and by a titration that precisely reproduced a known dissocation constant for Thermoplasma acidophilum CS (TpCS) (9).

Carboxymethyldethia-coenzyme $A(C M X)$. Inorganic salts and excess 4-aminobutyric acid were removed by diafiltration following the nucleotide thioester aminolysis step (5). Crude CMX (100 mL of a $3 \mathrm{mM}$ aqueous solution) was applied to a DEAE Sepharose Fast Flow column $(2.5 \mathrm{x} 25 \mathrm{~cm})$, which was developed with a linear gradient of $\mathrm{LiCl}(0-0.20 \mathrm{M}, 1$ x $1 \mathrm{~L})$ in $3 \mathrm{mM} \mathrm{HCl}$. CMX eluted at $0.08-0.10 \mathrm{M}$ LiCl. After diafiltration to remove inorganic salts, and lyophilization, CMX was obtained as a white solid (total yield 20\%). Analytical HPLC: $\mathrm{t}_{\mathrm{R}}=6.4 \mathrm{~min}, \lambda_{\max }=260 \mathrm{~nm}$. For analysis, a C18 cartridge (SEP-PAK, Waters Associates) was used to prepare the free acid of CMX. CMX (2 mL of a $2 \mu \mathrm{M}$ solution) was acidified with $1 \mathrm{M} \mathrm{H}_{3} \mathrm{PO}_{4}$ to $\mathrm{pH} 2$ (versus $\mathrm{pH}$ paper) and loaded onto the $\mathrm{C} 18$ cartridge (prewashed with methanol and $3 \mathrm{mM} \mathrm{HCl})$. The cartridge was washed with $3 \mathrm{mM} \mathrm{HCl}(2 \mathrm{~mL})$ and $\mathrm{CMX}$ free acid was eluted with $25 \%$ methanol in water and dried in vacuum. ${ }^{1} \mathrm{H} \mathrm{NMR}$ (as the free acid, $500 \mathrm{MHz}, \mathrm{D}_{2} \mathrm{O}$ ): 0.82 $(\mathrm{s}, 3 \mathrm{H}), 0.93(\mathrm{~s}, 3 \mathrm{H}), 1.74$ (quintet, $2 \mathrm{H}, J=7.0 \mathrm{~Hz}), 2.36(\mathrm{t}, 2 \mathrm{H}, J=7.5 \mathrm{~Hz}), 2.44(\mathrm{t}, 2 \mathrm{H}, J=6.3 \mathrm{~Hz}), 3.16$ $(\mathrm{t}, 2 \mathrm{H}, J=7.0 \mathrm{~Hz}), 3.45(\mathrm{t}, 2 \mathrm{H}, J=6.5 \mathrm{~Hz}), 3.65(\mathrm{dd}, 1 \mathrm{H}, J=4.5,10.0 \mathrm{~Hz}), 3.88(\mathrm{dd}, 1 \mathrm{H}, J=4.5,10.0 \mathrm{~Hz})$, 
$4.00(\mathrm{~s}, 1 \mathrm{H}), 4.27(\mathrm{br}, 2 \mathrm{H}), 4.60(\mathrm{br}, 1 \mathrm{H}), 6.18(\mathrm{~d}, 1 \mathrm{H}, J=6 \mathrm{~Hz}), 8.41(\mathrm{~s}, 1 \mathrm{H}), 8.61(\mathrm{~s}, 1 \mathrm{H}) .{ }^{13} \mathrm{C} \mathrm{NMR}(\mathrm{as}$ free acid, $\left.125 \mathrm{MHz}, \mathrm{D}_{2} \mathrm{O}\right): 17.50,19.93,22.96,30.27,34.52,34.67,37.58,37.75,64.36,71.43(\mathrm{~d}, J=6.1$ Hz), 72.98, 73.42, 73.59, 82.38, 86.73, 117.66, 141.65, 143.96, 147.63, 149.01, 173.07, 173.92, 177.15. HRMS (ESI): $[\mathrm{M}+\mathrm{H}]^{+}$calcd for $\mathrm{C}_{23} \mathrm{H}_{38} \mathrm{O}_{18} \mathrm{~N}_{7} \mathrm{P}_{3} m / z$ 794.1564, found 794.1570.

Overexpression and Purification of $A a C S^{\text {dye }}$. An overnight culture was used to inoculate a $1 \mathrm{~L}$ culture in LB/amp medium in a $4 \mathrm{~L}$ Erlenmeyer flask, which was agitated for $16-18 \mathrm{~h}$ at $37^{\circ} \mathrm{C}$ without the addition of an inducer. Cells (typically $7 \mathrm{~g}$ per L culture) were harvested by centrifugation and either used immediately or stored at $-80{ }^{\circ} \mathrm{C}$. All subsequent steps were performed at $4{ }^{\circ} \mathrm{C}$. Cells were resuspended in Tris buffer (50 mM Tris-Cl, $\mathrm{pH} 8.0$ ) at $5 \mathrm{~mL} / \mathrm{g}$ and disrupted by sonication. Debris was removed by centrifugation and streptomycin sulfate was added from a $10 \%(w / v)$ stock solution, to a final concentration of $1 \%$. After 10 min of stirring, solids were removed by centrifugation. The supernatant was adjusted to $35 \%$ saturation by the addition of solid ammonium sulfate $(208 \mathrm{~g} / \mathrm{L})$ with stirring over $60 \mathrm{~min}$; solids were removed by centrifugation. The supernatant was adjusted to $85 \%$ saturation by the addition of solid ammonium sulfate (358 g/L) with stirring over $60 \mathrm{~min}$; the precipitate was then collected by centrifugation, dissolved in a small volume of Tris buffer $(<10 \mathrm{~mL})$, and desalted on Sephadex G50 resin. The desalted protein was concentrated to $\sim 15 \mathrm{~mL}$, and applied to DE-52 $(3.0 \times 2.5 \mathrm{~cm})$ equilibrated in Tris buffer. Since CS breaks through in this step, fractions were collected during loading and subsequent washing with Tris buffer (120 $\mathrm{mL}$ ). Fractions containing CS activity were pooled, concentrated to $\sim 10 \mathrm{~mL}$, and applied to Blue Sepharose $(1.5 \times 11 \mathrm{~cm})$ equilibrated in Tris buffer. The column was washed with $400 \mathrm{~mL}$ of Tris buffer and developed in a linear gradient of $\mathrm{KCl}(0 \rightarrow 0.5 \mathrm{M}, 500 \times 500 \mathrm{~mL})$. Fractions containing CS activity were pooled, concentrated to $>5 \mathrm{mg} / \mathrm{mL}$, and frozen in single-use aliquots at $-80{ }^{\circ} \mathrm{C}$.

Purification of AaCSH6. Cells were resuspended in buffer $\mathrm{H}(20 \mathrm{mM}$ Tris-Cl pH 8.0, $100 \mathrm{mM} \mathrm{KCl})$ at $10 \mathrm{~mL}$ per g cells and disrupted by sonication. Cell debris was removed by centrifugation for $30 \mathrm{~min}$ at $35,000 \times \mathrm{g}$ and streptomycin sulfate was added from a $10 \%(w / v)$ stock solution to a final concentration of 1\%. After $10 \mathrm{~min}$ of stirring, solids were removed by centrifugation for $10 \mathrm{~min}$ at 3,000 x $g$ and the supernatant was adjusted to $35 \%$ saturation by the addition of solid ammonium sulfate (208 g/L) over 30 min. After stirring another $30 \mathrm{~min}$, solids were removed by centrifugation for $30 \mathrm{~min}$ at 15,000 x $g$. The supernatant was adjusted to $75 \%$ saturation by the addition of solid ammonium sulfate ( $275 \mathrm{~g} / \mathrm{L})$ over 30 min. Solids were collected by centrifugation for $30 \mathrm{~min}$ at $15,000 \mathrm{x} g$ and dissolved in buffer $\mathrm{H}$ containing $20 \mathrm{mM}$ imidazole $\left(1 \mathrm{~mL}\right.$ per starting g cells). The solution was applied to IDA-Ni ${ }^{2+}(2.5 \times 5.0 \mathrm{~cm})$, which 
was washed with buffer $\mathrm{H}$ containing $20 \mathrm{mM}$ imidazole $(250 \mathrm{~mL})$. The column was then developed in a linear gradient of imidazole $(20 \rightarrow 500 \mathrm{mM}, 100 \times 100 \mathrm{~mL})$ in buffer H. SDS-PAGE was used to identify fractions containing pure AaCSH6, which were pooled (ca. $80 \mathrm{~mL}$ ) and concentrated. The concentration of imidazole was reduced to 5-10 mM by several cycles of dilution-reconcentration in buffer $\mathrm{H}$. An equal volume of buffer $\mathrm{H}$ containing $20 \%$ glycerol was mixed with concentrated enzyme $(10-50 \mathrm{mg} / \mathrm{mL})$ to give a final concentration of $10 \%(\mathrm{v} / \mathrm{v})$ glycerol. Aliquots were frozen in dry ice and stored at $-80{ }^{\circ} \mathrm{C}$ until use.

Thiol determinations. For thiol determinations, protein was mixed with $0.5 \mathrm{mM}$ DTNB in either 100 $\mathrm{mM}$ potassium phosphate $(\mathrm{pH} 7.27), 1 \mathrm{mM}$ EDTA $\left(\varepsilon_{412}=14.1 \mathrm{mM}^{-1} \mathrm{~cm}^{-1}\right)$ at $0.88 \mathrm{mg} / \mathrm{mL}$ or $100 \mathrm{mM}$ potassium phosphate $(\mathrm{pH} 7.27), 1 \mathrm{mM}$ EDTA, $6.4 \mathrm{M}$ guanidine $\cdot \mathrm{Cl}\left(\varepsilon_{412}=13.7 \mathrm{mM}^{-1} \mathrm{~cm}^{-1}\right)$ at $0.18 \mathrm{mg} / \mathrm{mL}$ (10). Averages of three assays for the folded and unfolded AaCS forms were taken and the number of cysteines calculated for each subunit.

Determination of extinction coefficients. AcCoA was standardized in water $\left(\varepsilon_{260}=16.4 \mathrm{mM}^{-1} \mathrm{~cm}^{-1}\right)(11)$. The $\Delta \varepsilon$ at $233 \mathrm{~nm}$ needed for assay B (below) was determined by adding $>10$ small aliquots of AcCoA $(0.4$ $\mathrm{mM})$, OAA $(10 \mathrm{mM})$, citrate $(50 \mathrm{mM})$, or $\operatorname{CoA}(1.5 \mathrm{mM})$ to solutions containing $50 \mathrm{mM}$ buffer and 100 $\mathrm{mM} \mathrm{KCl}$, using $\mathrm{KOH}$ to adjust $\mathrm{pH}$. The buffer was either potassium phosphate (pH $3.2-8.0$ ) or CHES ( $\mathrm{pH} 8.5)$.

Determination of OAA binding constants. A Spex Fluoromax fluorimeter was used to acquire emission spectra in a stirred, thermostatted cuvette maintained at $25^{\circ} \mathrm{C}$ (temperature measured in the cuvette). All spectra were acquired in $S / R$ mode, where emission intensity was corrected for fluctuations in excitation intensity. The excitation wavelength was $295 \mathrm{~nm}$ (1 nm slit width) and emission intensity was monitored at $339 \mathrm{~nm}$ (5 nm slit width). Titrations were performed by adding small aliquots of 3 - $120 \mathrm{mM}$ OAA to 50 $\mathrm{mM}$ potassium phosphate (pH 4.7 or 8.0 ), $100 \mathrm{mM} \mathrm{KCl}, 2 \mathrm{mM}$ EDTA, and $1 \mu \mathrm{M}$ (subunit concentration) of each $\mathrm{AaCS}$ form in an initial volume of $3 \mathrm{~mL}$. After a 1 min equilibration period, emission spectra were obtained (300 - $420 \mathrm{~nm}, 1 \mathrm{~nm}$ interval, $0.5 \mathrm{~s}$ integration). The intensity of the fluorescence emission $F$ in each titration was corrected for dilution and inner filter effects, and when desired, for photodecomposition of $A a \mathrm{CS}$. N-acetyltryptophanamide was used to correct for inner filter effects. Protein photodecomposition was monitored in parallel experiments that were either irradiated continuously or following variable intervals of stirring in the dark. Photodecomposition rates were obtained for each $A a C S$ form in the presence or absence of $25 \mu \mathrm{M}$ OAA. Titration data were fit using known values of $C=$ [OAA] 
and $E=$ enzyme subunit concentration, to three parameters (Equation $\mathrm{S} 1): K_{\mathrm{d}}=$ dissociation constant, $F_{\mathrm{o}}=$ initial $F$, and $\Delta F=$ maximal change in $F$.

$$
F=F_{o}-\frac{\Delta F}{2}\left((C+E+K)-\sqrt{(C+E+K)^{2}-4 E C}\right)
$$

Alternative Substrates and Inhibitors. In enzymatic activity assay mixtures (assay A) lacking either AcCoA or OAA, respectively, $n$-propionyl-CoA (PrCoA) and $\alpha$-ketoglutarate $(\alpha \mathrm{KG})$ were examined as potential alternate substrates. $\alpha \mathrm{KG}$ was tested for inhibition in standard activity assay $\mathrm{A}$. In enzymatic activity assay mixtures (assay B) lacking OAA and AcCoA, the chemical intermediate CitCoA was examined at pHs 3.8, 4.0, 5.0, 6.0, and 8.0. Buffers used were the same as those for the pH-rate profile.

Acetate and citrate were examined as inhibitors in assay B at $\mathrm{pH} 4.0$ or 8.0 at saturating $\left(5 \times K_{\mathrm{m}}\right)$ or subsaturating $\left(1 \times K_{\mathrm{m}}\right)$ levels of OAA or AcCoA. Buffers were the same as those for the pH-rate profile. The ability of acetate to inhibit PCS was determined at $\mathrm{pH} 8.0$ under saturating or unsaturating levels of AcCoA or OAA. $K_{\mathrm{i}}$ and $\alpha K_{\mathrm{i}}$ values were determined using an Excel (Microsoft) template for calculation of enzyme kinetic parameters by non-linear regression (12).

The effect of NADH on $A a C S$ activity was examined using two experiments. First, specific activities were surveyed at several $\mathrm{KCl}(0,0.1,0.2$, and $0.4 \mathrm{M})$ and $\mathrm{NADH}(0,50,100,200$, and $500 \mu \mathrm{M})$ concentrations. Second, the inhibition pattern was determined using standard assay A conditions except that AcCoA was varied from 9 to $160 \mu \mathrm{M}$ and $\mathrm{NADH}$ was present at fixed concentrations ranging from 0 to $100 \mathrm{mM}$. Kinetic constants were obtained using Excel to fit all data to an equation for noncompetitive inhibition (13).

Determination of OAA Decomposition Rates. OAA decomposition to pyruvate $\left(\right.$ and $\left.\mathrm{CO}_{2}\right)$ was monitored by analytical HPLC. HPLC experiments were carried out on a Waters Breeze system with a 717plus autosampler, a Waters Symmetry C18 column (4.6 x $150 \mathrm{~mm}, 5 \mu \mathrm{m})$, and a 2487 dual wavelength absorbance detector monitoring at 215 and $260 \mathrm{~nm}$. The average temperature in the autosampler was 23.0 $\pm 0.5^{\circ} \mathrm{C}$. Solvents used were aqueous $20 \mathrm{mM}$ tert-butyl ammonium hydroxide and $25 \mathrm{mM}$ ammonium sulfate, $\mathrm{pH} 5.3$ (solvent A) and acetonitrile (solvent B). Compounds were eluted at a flow rate of 0.8 $\mathrm{mL} / \mathrm{min}$ with a linear gradient from $10 \%$ to $20 \%$ solvent B over 20 min before a decreasing linear gradient to $10 \%$ solvent B over 1 min, followed by re-equilibration with $10 \%$ solvent B for 14 min. 
The OAA decomposition mixture contained $50 \mathrm{mM}$ potassium phosphate, $100 \mathrm{mM} \mathrm{KCl,} 2 \mathrm{mM}$ EDTA, $0.5 \mathrm{mM}$ OAA, and $0.1 \mathrm{mM}$ uracil as a standard, at various $\mathrm{pH}$ values ranging from 3.5 to 9 , in a final volume of $1 \mathrm{~mL}$. OAA lifetimes were determined by injecting $10 \mu \mathrm{L}$ aliquots over time. The relative areas of uracil (retention time $2.1 \mathrm{~min})$, pyruvate $(6.6 \mathrm{~min})$, and OAA (17.6 min; some tailing observed) were determined using the Breeze software. Areas were normalized to the uracil peak, assuming $[\mathrm{OAA}]_{0}=A_{0}=$ $[\mathrm{OAA}]_{\mathrm{t}}+[\text { pyruvate }]_{\mathrm{t}}$, and used to determine concentrations at each time point. Progress curves were then fit to Equation $\mathrm{S} 2$, where $k$ (rate) and $x$ (intercept) were the only varied parameters. The $\mathrm{pH}$ was measured at the end of each experiment, and in all cases it had not changed.

$$
C=\left(A_{0}-x\right) \exp [-k t]+x
$$




\section{RESULTS}

Thiol quantitation indicates the presence of $3.6 \pm 0.2$ reduced Cys per subunit of unfolded $A a \mathrm{CS}^{\text {dye }}$ (folded $A a \mathrm{CS}^{\mathrm{dye}}=0.7 \pm 0.2$ ), and $3.9 \pm 0.3$ reduced Cys per subunit of unfolded AaCS ${ }^{\text {intein }}$ (folded $A a \mathrm{CS}^{\text {intein }}=0.14 \pm 0.01$ ), indicating that no disulfides are present among the four Cys in $A a C S$. Since the dye-affinity isolation procedure is carried out in the absence of reducing agents, we conclude $\mathrm{AaCS}$ also does not readily oxidize.

We performed steady-state product inhibition studies to determine the effect of the product citric acid and the abundant potential competitor acetic acid on AaCS activity, and found that they are both low $\mathrm{mM}$ inhibitors (Table S4). Product inhibition patterns were consistent with an Ordered Bi-Bi reaction mechanism.

$E c \mathrm{CS}$ is inhibited by $\alpha \mathrm{KG}(14)$. $\alpha \mathrm{KG}$ is neither a substrate nor an inhibitor $\left(K_{\mathrm{i}}<10 \mathrm{mM}\right)$ of $A a \mathrm{CS}$.

PrCoA is a CS inhibitor and occasional alternate substrate (15-17). PrCoA was a very poor substrate for AaCSH6, with $k_{\text {cat }}=1.2 \mathrm{~min}^{-1}$ and $K_{\mathrm{m}}=34 \mu \mathrm{M}\left(k_{\text {cat }} / K_{\mathrm{m}}=0.02 \%\right.$ of AcCoA $)$, consistent with a primary function in the citric acid cycle, not in a biosynthetic role (18).

CitCoA was a slightly better substrate for $A a C S$ than AcCoA with $k_{\text {cat }}=5400 \min ^{-1}$ and $K_{\mathrm{m}}=16.3 \mu \mathrm{M}$ at pH 8.0 (Figure S2). EcCS and AaCS have similar $K_{\mathrm{m}}$ values for CitCoA (19). Over a range of acidic $\mathrm{pH}$, AcCoA and CitCoA are comparable $A a C S$ substrates, indicating that hydrolysis is rate-limiting, as it is for other CS forms (20). The complicated kinetics of CitCoA consumption by PCS and other CS forms (19, 21) are not observed with $A a \mathrm{CS}$. 


\section{REFERENCES}

(1) Ausubel, F. M., Brent, R., Kingston, R. E., Moore, D. D., Seidman, J. D., Smith, J. A., and Struhl, K. (2000) Current Protocols in Molecular Biology, John Wiley \& Sons, New York.

(2) Sambrook, J., Fritsch, G. F., and Maniatis, T. (1989) Molecular cloning: A laboratory guide, 2nd ed., Cold Springs Harbor Laboratory Press.

(3) Bradford, M. M. (1976) A rapid and sensitive method for the quantitation of microgram quantities of protein utilizing the principle of protein-dye binding. Anal. Biochem. 72, 248-254.

(4) Constantine, C. Z., Starks, C. M., Mill, C. P., Ransome, A. E., Karpowicz, S. J., Francois, J. A., Goodman, R. A., and Kappock, T. J. (2006) Biochemical and structural studies of $N^{5}$ carboxyaminoimidazole ribonucleotide mutase (PurE) from the acidophilic bacterium Acetobacter aceti. Biochemistry 45, 8193-8208.

(5) Martin, D. P., Bibart, R. T., and Drueckhammer, D. G. (1994) Synthesis of novel analogs of acetyl coenzyme A: Mimics of enzyme reaction intermediates. J. Am. Chem. Soc. 116, 4660-4668.

(6) Xun, J. (2002) Ph.D. thesis, State University of New York at Stony Brook.

(7) Strauss, E., and Begley, T. P. (2002) The antibiotic activity of $N$-pentylpantothenamide results from its conversion to ethyldethia-coenzyme A, a coenzyme A antimetabolite. J. Biol. Chem. 277, 48205-48209.

(8) Calder, R. B., Williams, R. S. B., Ramaswamy, G., Rock, C. O., Campbell, E., Unkles, S. E., Kinghorn, J. R., and Jackowski, S. (1999) Cloning and characterization of a eukaryotic pantothenate kinase gene (panK) from Aspergillus nidulans. J. Biol. Chem. 274, 2014-2020.

(9) Kurz, L. C., Roble, J. H., Nakra, T., Drysdale, G. R., Buzan, J. M., Schwartz, B., and Drueckhammer, D. G. (1997) Ability of single-site mutants of citrate synthase to catalyze proton transfer from the methyl group of dethiaacetyl-coenzyme A, a non-thioester substrate analog. Biochemistry 36, 3981-90.

(10) Riddles, P. W., Blakeley, R. L., and Zerner, B. (1983) Reassessment of Ellman's reagent. Methods Enzymol. 91, 49-60. 
(11) Dawson, R. M. C. (1986) Data for biochemical research, 3rd ed., Clarendon Press, Oxford.

(12) Hernandez, A., and Ruiz, M. T. (1998) An EXCEL template for calculation of enzyme kinetic parameters by non-linear regression. Bioinformatics 14, 227-228.

(13) Cleland, W. W. (1979) Statistical analysis of enzyme kinetic data. Methods Enzymol. 63, 103-138.

(14) Wright, J. A., Maeba, P., and Sanwal, B. D. (1967) Allosteric regulation of the activity of citrate synthetase of Escherichia coli by $\alpha$-ketoglutarate. Biochem. Biophys. Res. Commun. 29, 34-38.

(15) Weidman, S. W., and Drysdale, G. R. (1979) The biosynthesis of methylcitrate. Biochem. J. 177, 169-174.

(16) Smith, C. M., and Williamson, J. R. (1971) Inhibition of citrate synthase by succinyl-CoA and other metabolites. FEBS Lett. 18, 35-38.

(17) Brandange, S., Josephson, S., Mahlen, A., Morch, L., Sweetman, L., and Vallen, S. (1977) Stereochemistry of the methylcitric acids formed in the citrate synthase reaction with propionyl-CoA. Acta Chem. Scand. 31, 628-630.

(18) Danson, M. J., and Hough, D. W. (2001) Citrate synthase from hyperthermophilic Archaea. Methods Enzymol. 331, 3-12.

(19) Lohlein-Werhahn, G., Goepfert, P., Kollmann-Koch, A., and Eggerer, H. (1988) Studies on the citryl-CoA-dependent inhibition of citrate-synthase with source variants from baker's yeast, Escherichia coli and Sulfolobus solfataricus. Biol. Chem. Hoppe Seyler 369, 417-424.

(20) Kurz, L. C., Drysdale, G., Riley, M., Tomar, M. A., Chen, J., Russell, R. J. M., and Danson, M. J. (2000) Kinetics and mechanism of the citrate synthase from the thermophilic archaeon Thermoplasma acidophilum. Biochemistry 39, 2283-2296.

(21) Kurz, L. C., Shah, S., Frieden, C., Nakra, T., Stein, R. E., Drysdale, G. R., Evans, C. T., and Srere, P. A. (1995) Catalytic strategy of citrate synthase: subunit interactions revealed as a consequence of a single amino acid change in the oxaloacetate binding site. Biochemistry 34, 13278-13288. 
(22) Guex, N., and Peitsch, M. C. (1997) SWISS-MODEL and the Swiss-PdbViewer: an environment for comparative protein modeling. Electrophoresis 18, 2714-2723.

(23) Thompson, J. D., Higgins, D. G., and Gibson, T. J. (1994) CLUSTAL W: improving the sensitivity of progressive multiple sequence alignment through sequence weighting, position-specific gap penalties and weight matrix choice. Nucleic Acids Res. 22, 4673-4680.

(24) Gouet, P., Courcelle, E., Stuart, D. I., and Metoz, F. (1999) ESPript: analysis of multiple sequence alignments in PostScript. Bioinformatics 15, 305-308. 
TABLES.

Table S1. Oligodeoxynucleotides (ODNs) used in this study.

\begin{tabular}{ll}
\hline ODN \# & Sequence $\left(5^{\prime} \rightarrow 3^{\prime}\right)$ \\
\hline 413 & GAGCTCGAATTCTTAGCGTTTGGCAAGCGGCACATAGTCAC \\
416 & GATATACATATGAGCGCGTCGCAGAAAGAAGGTAAGCTATC \\
532 & CCTTCATCCACCAACGTCGAC \\
554 & GATCGTCGACGTTGG \\
844 & GGCAGCCATATGAGTATAAAAGATCAAACG \\
845 & GAGCTCGAATTCTTATTTGCGTAGTCTGACCTC \\
865 & GCTTGCCAAACGCCTCGAGCACCACC \\
866 & GGTGGTGCTCGAGGCGTTTGGCAAGC \\
867 & CCGCTTGCCAAACGCTGCATCACGGGAGATG \\
868 & CATCTCCCGTGATGCAGCGTTTGGCAAGCGG \\
884 & GTGGCAGCTTCACCACCACCACCACCACTGAGATCCGGCTGCT \\
885 & AGCAGCCGGATCTCAGTGGTGGTGGTGGTGGTGAAGCTGCCAC \\
\hline
\end{tabular}


Table S2. Purification of $A a \mathrm{CS}^{\text {dye }}$

\begin{tabular}{lllll}
\hline Step & Protein $(\mathrm{mg})$ & Activity (U) & SA (U/mg) & Yield (\%) \\
\hline Soluble lysate & & 5525 & 16 & 100 \\
$35-85 \%\left(\mathrm{NH}_{4}\right)_{2} \mathrm{SO}_{4}$ & 280 & 4420 & 16 & 80 \\
G50 & 200 & 2262 & 11 & 41 \\
DE-52 & 41 & 1800 & 44 & 33 \\
Blue Sepharose & 13 & 1658 & 127 & 30 \\
\hline
\end{tabular}

${ }^{\mathrm{a}}$ Starting from $18 \mathrm{~g}$ B834(DE3) cells transformed with pJK136.

${ }^{\mathrm{b}} \mathrm{AaCS}$ is mostly located in the breakthrough from this step. 
Table S3. Purification of $A a C S^{\text {intein }}$ from $A a C S-i n t e i n-C B D-H 6$ fusion.

\begin{tabular}{llllll}
\hline Step & Protein $(\mathrm{mg})$ & Activity (U) & SA (U/mg) & Fold purif. & Yield (\%) \\
\hline Soluble lysate $^{\mathrm{a}}$ & 160 & 1650 & 11 & 1 & 100 \\
IDA-Ni $^{2+}$ & 42 & 1620 & 38 & 3.5 & 98 \\
Chitin, concentrated $^{\mathrm{b}}$ & 6 & 740 & 123 & 12 & 45 \\
\hline
\end{tabular}

${ }^{\mathrm{a}}$ Starting from $9 \mathrm{~g} \mathrm{BL21(DE3)} \mathrm{cells} \mathrm{transformed} \mathrm{with} \mathrm{pJK240.}$

${ }^{\mathrm{b}}$ At this stage, nearly all fusion protein is gone. Before this step, fusion protein contributes an unknown fraction of the observed activity. 
Table S4. Inhibition of $\mathrm{AaCS}$ and PCS.

\begin{tabular}{|c|c|c|c|c|c|c|}
\hline $\begin{array}{l}\text { Fixed substrate \& } \\
\text { concentration }\end{array}$ & $\begin{array}{l}\text { Varied } \\
\text { substrate }\end{array}$ & Inhibitor & $\mathrm{CS}$ & Pattern $^{a}$ & $\begin{array}{l}K_{\mathrm{i}}, \mathrm{mM} \\
\mathrm{pH} 8(\mathrm{pH} 4)\end{array}$ & $\begin{array}{l}\alpha K_{\mathrm{i}}, \mathrm{mM} \\
\mathrm{pH} 8(\mathrm{pH} 4)\end{array}$ \\
\hline \multirow[t]{3}{*}[\mathrm{OAA}]{$=K_{\mathrm{m}}$} & AcCoA & acetate & $A a \mathrm{CS}$ & MT & $5.6(0.9)$ & $9.7(2.6)$ \\
\hline & $\mathrm{AcCoA}$ & citrate & $A a \mathrm{CS}$ & MT & $4.9(1.3)$ & $8.4(3.5)$ \\
\hline & $\mathrm{AcCoA}$ & acetate & PCS & MT & $5.7^{\mathrm{b}}$ & 8.8 \\
\hline \multirow[t]{3}{*}[\mathrm{OAA}]{$=5 K_{\mathrm{m}}$} & $\mathrm{AcCoA}$ & acetate & $A a \mathrm{CS}$ & $\mathrm{C}$ & $3.0(0.5)$ & - \\
\hline & $\mathrm{AcCoA}$ & citrate & $A a \mathrm{CS}$ & $\mathrm{C}$ & $3.6(0.2)$ & - \\
\hline & $\mathrm{AcCoA}$ & acetate & PCS & $\mathrm{NC}$ & 6.3 & - \\
\hline \multirow[t]{3}{*}[\mathrm{AcCoA}]{$=K_{\mathrm{m}}$} & OAA & acetate & $A a \mathrm{CS}$ & $\mathrm{C}(\mathrm{MT})$ & $2.2(1.2)$ & $-(4.8)$ \\
\hline & OAA & citrate & $A a \mathrm{CS}$ & $\mathrm{C}(\mathrm{MT})$ & $2.1(2.4)$ & $-(15)$ \\
\hline & OAA & acetate & PCS & MT & 1.9 & 11 \\
\hline \multirow[t]{3}{*}[\mathrm{AcCoA}]{$=5 K_{\mathrm{m}}$} & OAA & acetate & $A a \mathrm{CS}$ & $\mathrm{NC}$ & $12(2.4)$ & - \\
\hline & OAA & citrate & $A a \mathrm{CS}$ & $\mathrm{NC}$ & $13(8.3)$ & 一 \\
\hline & OAA & acetate & PCS & MT & 5.1 & 9.4 \\
\hline
\end{tabular}

${ }^{a}$ Inhibition pattern. $\mathrm{C}$, competitive; MT, mixed type; $\mathrm{NC}=$ noncompetitive. Patterns are the same at $\mathrm{pH} 8$ and $\mathrm{pH} 4$, except where the $\mathrm{pH} 4$ pattern is given in parentheses.

${ }^{\mathrm{b}} \mathrm{PCS}$ inhibition patterns were determined at $\mathrm{pH} 8$ only. 


\section{FIGURES}

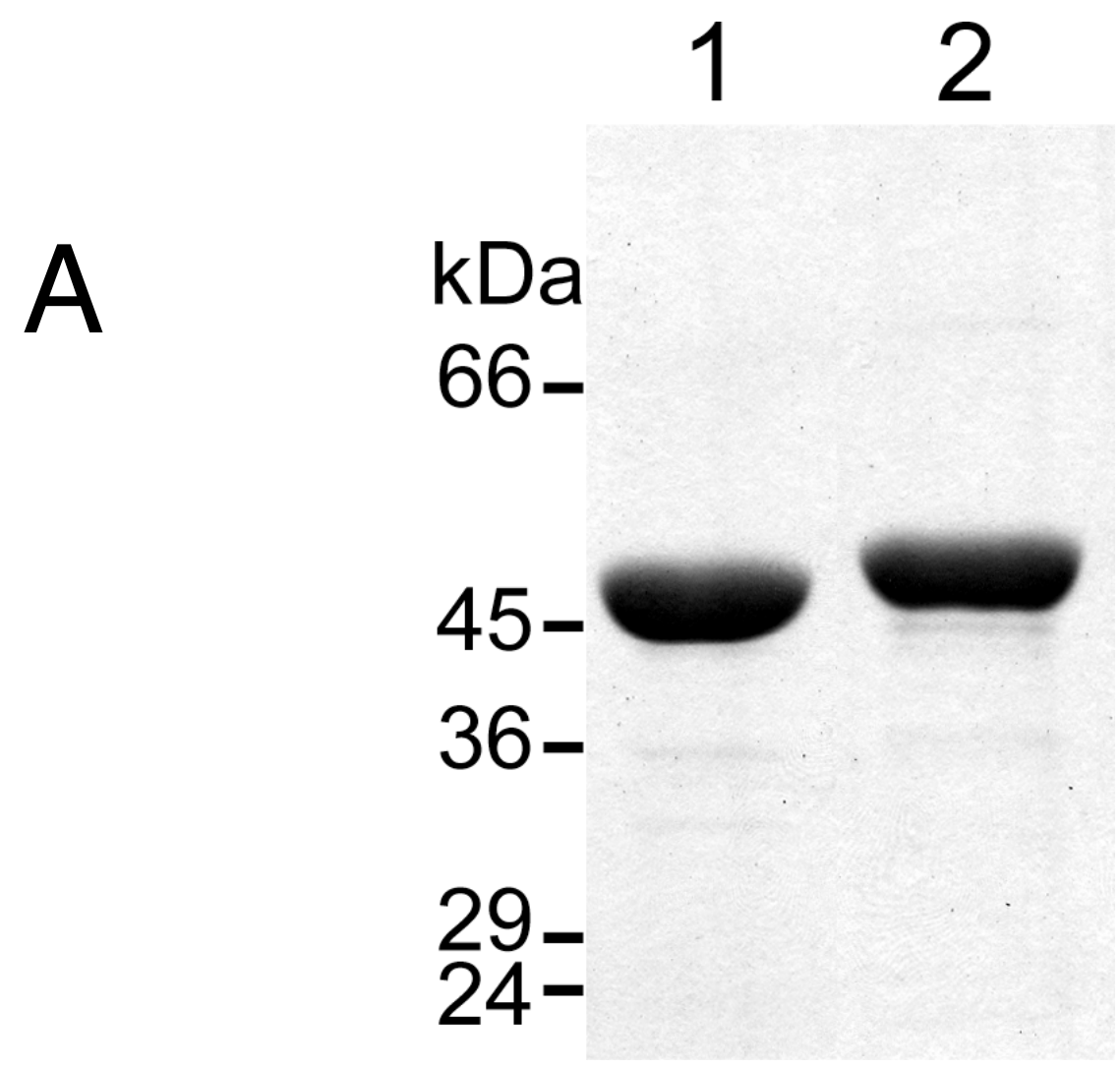

B

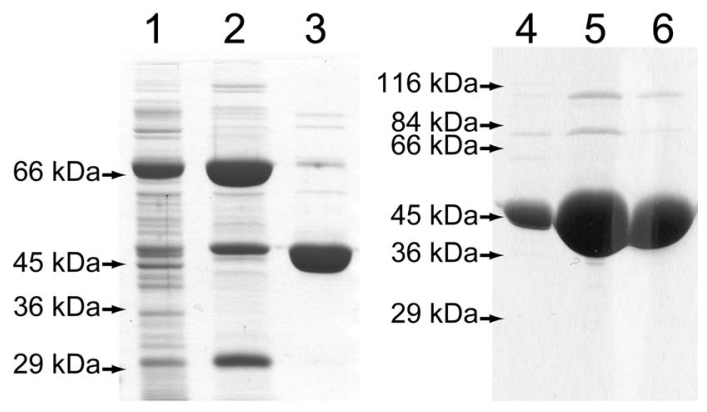

Figure S1. A, SDS-PAGE of purified recombinant $A a C S$ forms. Lane 1, AaCS ${ }^{\text {dye }}$, lane 2, AaCSH6. Each lane contains $5 \mu \mathrm{g}$ protein. Size standard positions are indicated. $B$, Purification of $A a \mathrm{CS}^{\text {intein }}$ from AaCS-intein-MBP-H6 fusion protein. Lane 1, soluble lysate. Lane 2, after IDA-Ni ${ }^{2+}$ column. Some cleavage of the intein fusion may occur in the SDS-PAGE reducing buffer. Lane 3, after chitin column. Lanes 1-3 contain $5 \mu \mathrm{g}$ protein. Lanes 4-6, successive fractions from Superdex 200 column used for protein crystallization. Size standard positions are indicated. 

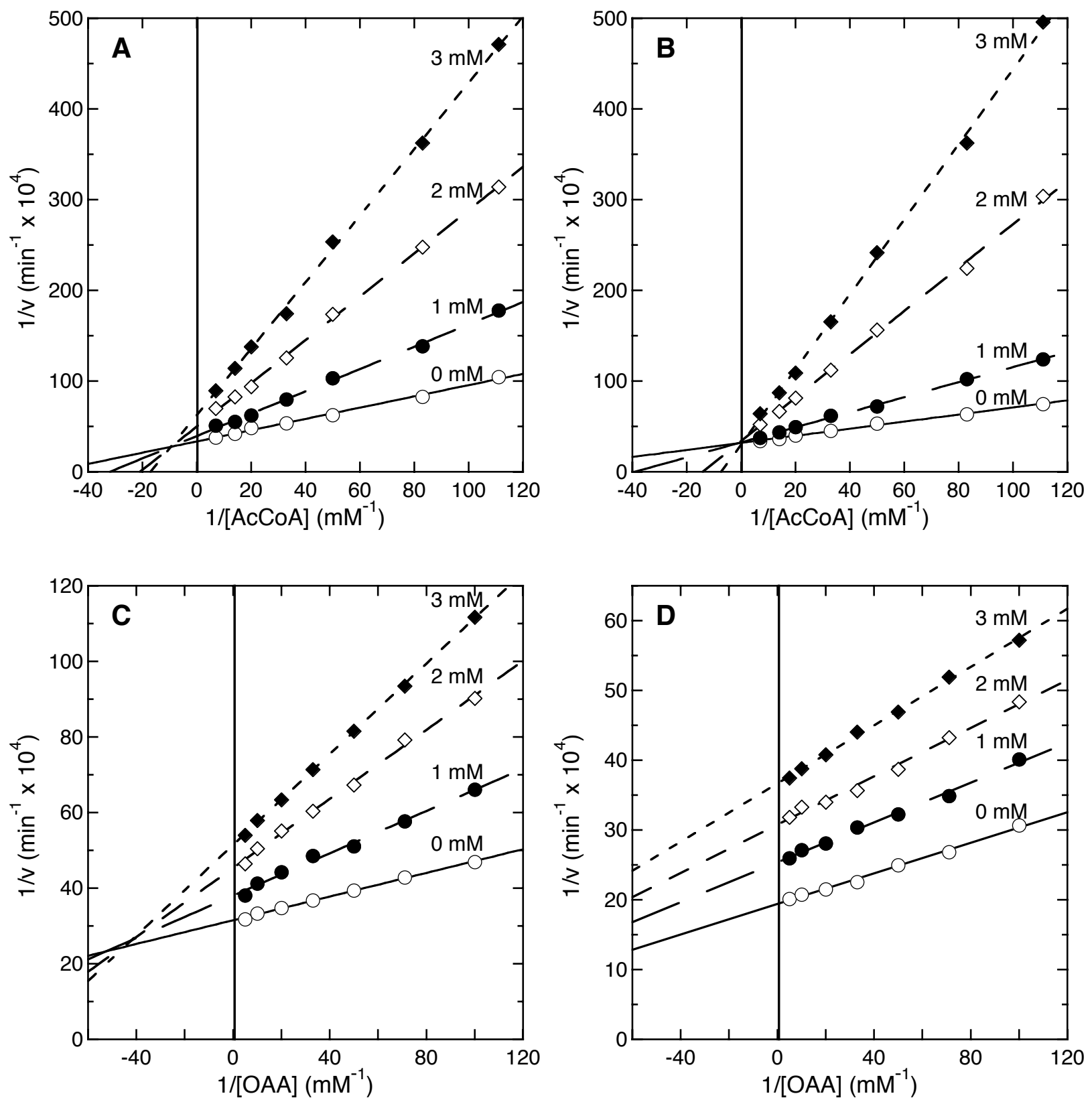

Figure S2. Double-reciprocal plots showing acetate inhibition of $A a \mathrm{CS}^{\mathrm{dye}}$ at $\mathrm{pH}$ 4. Acetate concentrations are $0,1,2$, or $3 \mathrm{mM}$ as indicated. $A,[\mathrm{OAA}]=K_{\mathrm{m}} \cdot B,[\mathrm{OAA}]=5 K_{\mathrm{m}} \cdot C,[\mathrm{AcCoA}]=K_{\mathrm{m}} \cdot D,[\mathrm{AcCoA}]=5$ $K_{\mathrm{m}}$. Lines are linear regressions for each fixed acetate concentration. Global fits to appropriate inhibition equations were used to derive the parameters presented in Table S4. 


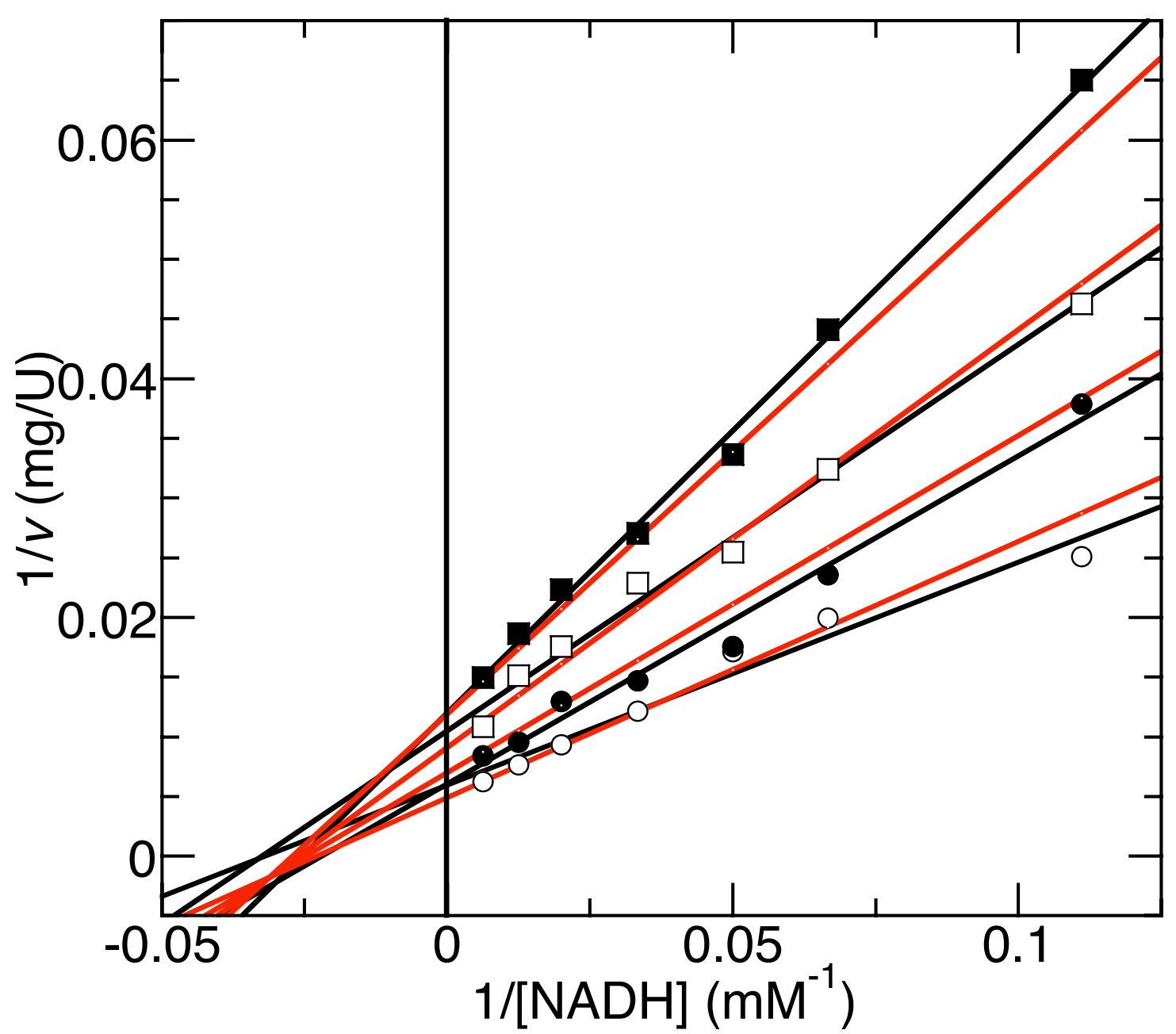

Figure S3. Double-reciprocal plot showing $A a \mathrm{CS}^{\text {intein }}$ inhibition at 0 (open circles), 30 (filled circles), 60 (open squares), and $100 \mathrm{mM}$ (filled squares) NADH. Black lines are linear regressions to each [NADH] dataset. Red lines represent a global fit to a noncompetitive inhibition model. 


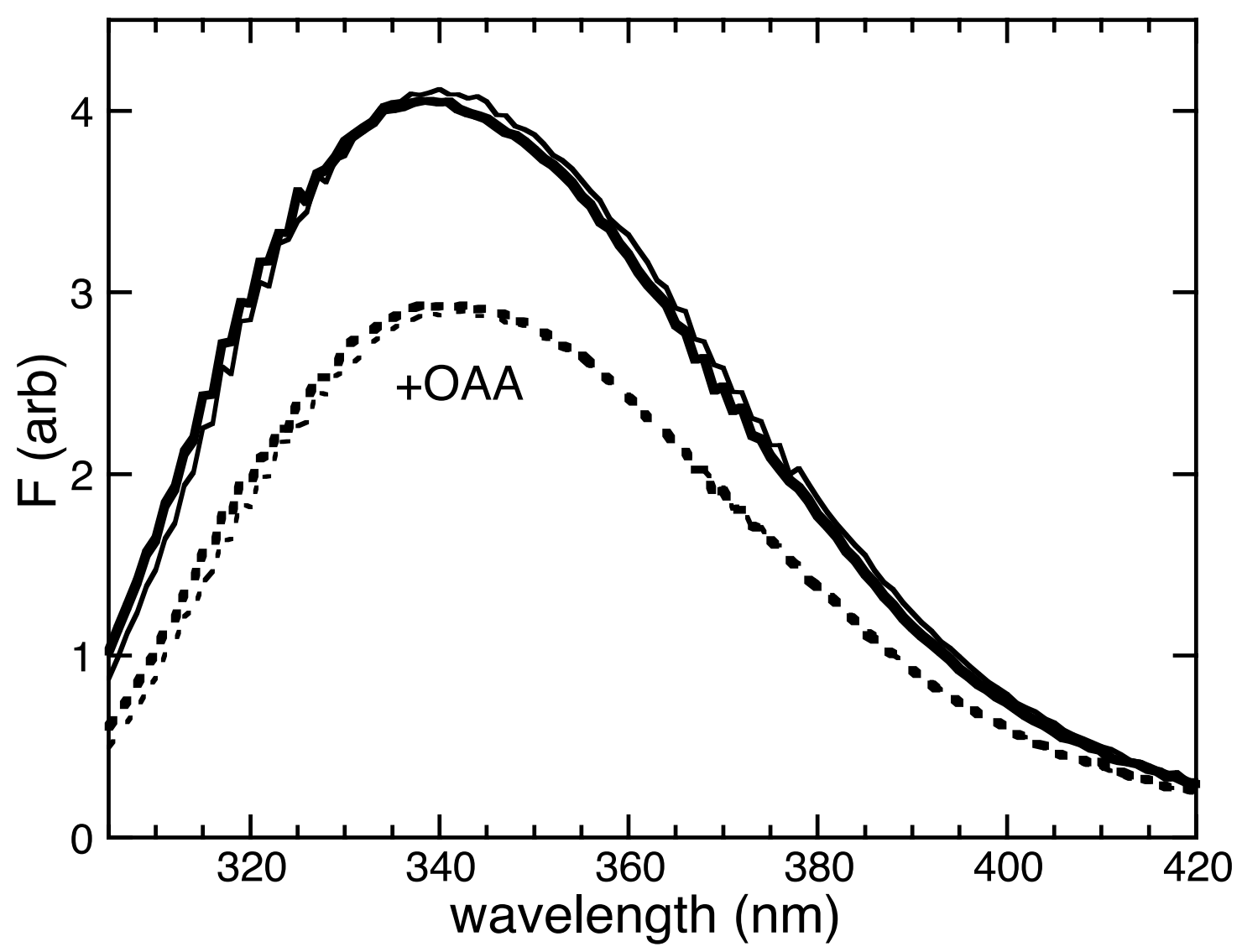

Figure S4. Fluorescence emission spectra measured for $A a \mathrm{CS}^{\mathrm{dye}}$ and $\mathrm{AaCSH} 6$ at $\mathrm{pH} 8.0$ and $25^{\circ} \mathrm{C}$. Spectra measured for $1 \mu \mathrm{MA} A \mathrm{CS}^{\mathrm{dye}}$ (thick lines) or $\mathrm{AaCSH} 6$ (thin lines) in the absence (solid lines) or presence (dotted lines) of $0.1 \mathrm{mM}$ OAA. Spectra have been corrected for dilution and, where appropriate, the inner filter effect caused by OAA. 

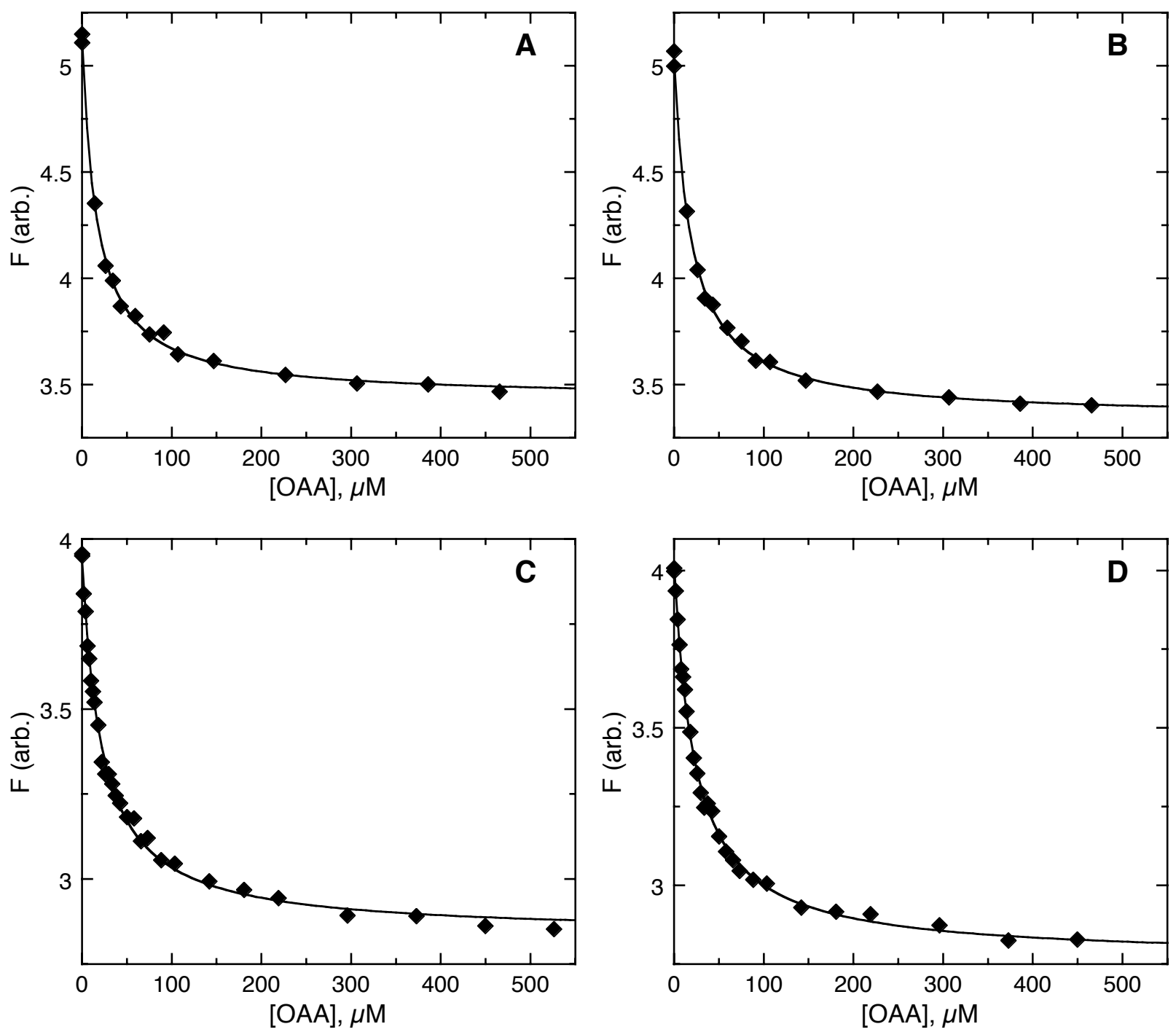

Figure S5. OAA $K_{\mathrm{d}}$ determinations for $A a \mathrm{CS}^{\mathrm{dye}}$ at $\mathrm{pH} 4.7$ (panel A) or $\mathrm{pH} 8.0$ (panel C) and for AaCSH6 at $\mathrm{pH} 4.7$ (panel B) or $\mathrm{pH} 8.0$ (panel D). In each panel the solid line is a fit to Equation S1 at $1 \mu \mathrm{M}$ $A a \mathrm{CS}^{\mathrm{dye}}$ or AaCSH6. Fitted values are given in Table 1. Titrations have been corrected for dilution and, where appropriate, the inner filter effect caused by OAA. Titrations were performed under conditions of minimal OAA decomposition, which is characterized in Figures S6 and S7. 

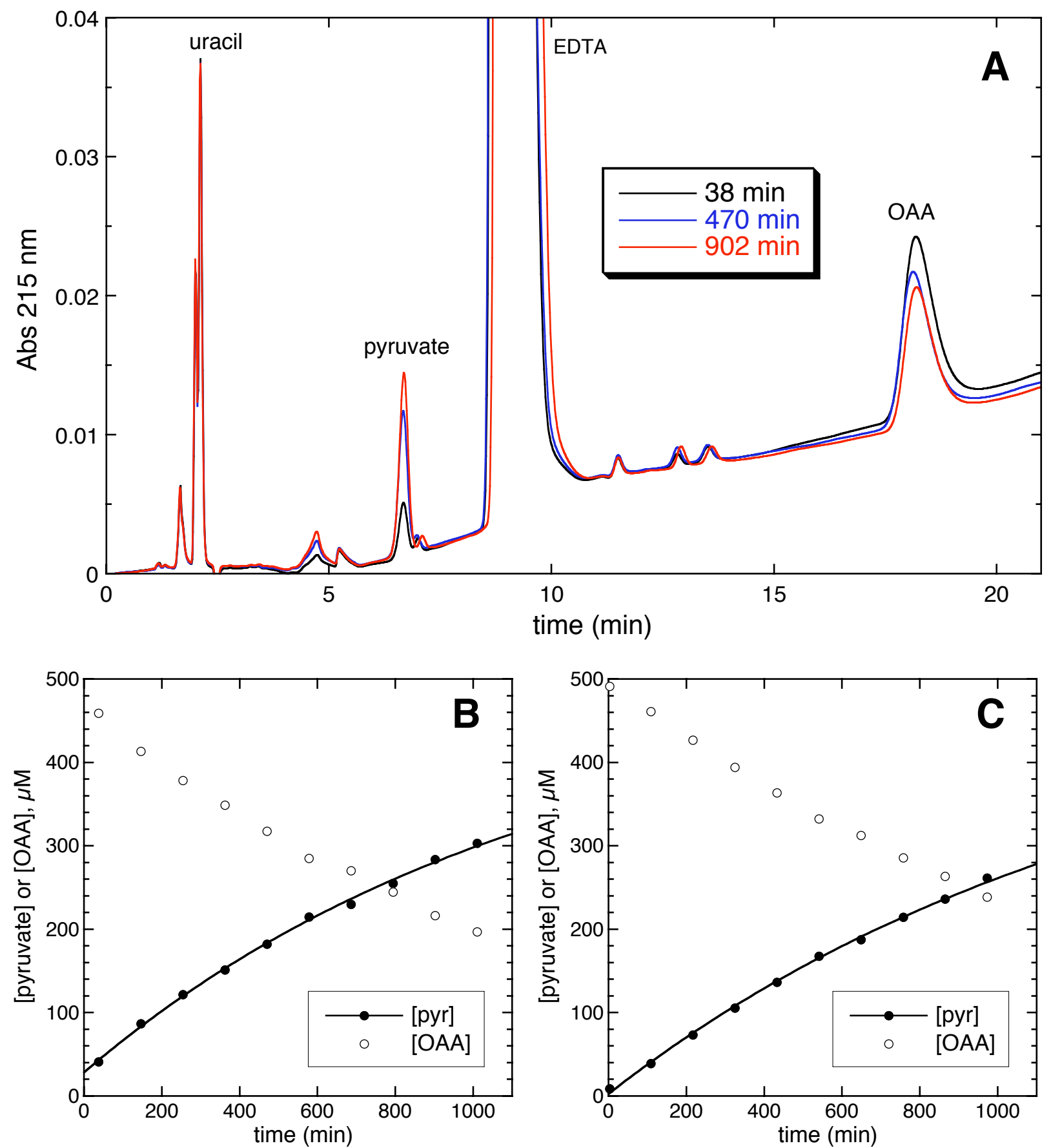

Figure S6. OAA stability. A, Example HPLC traces from incubation at $\mathrm{pH} 4.5$ at 38, 470, and $902 \mathrm{~min}$. $B$, Fit to pyruvate formation rate at $\mathrm{pH} 4.5$. $C$, Fit to pyruvate formation rate at $\mathrm{pH} 8.0$. 


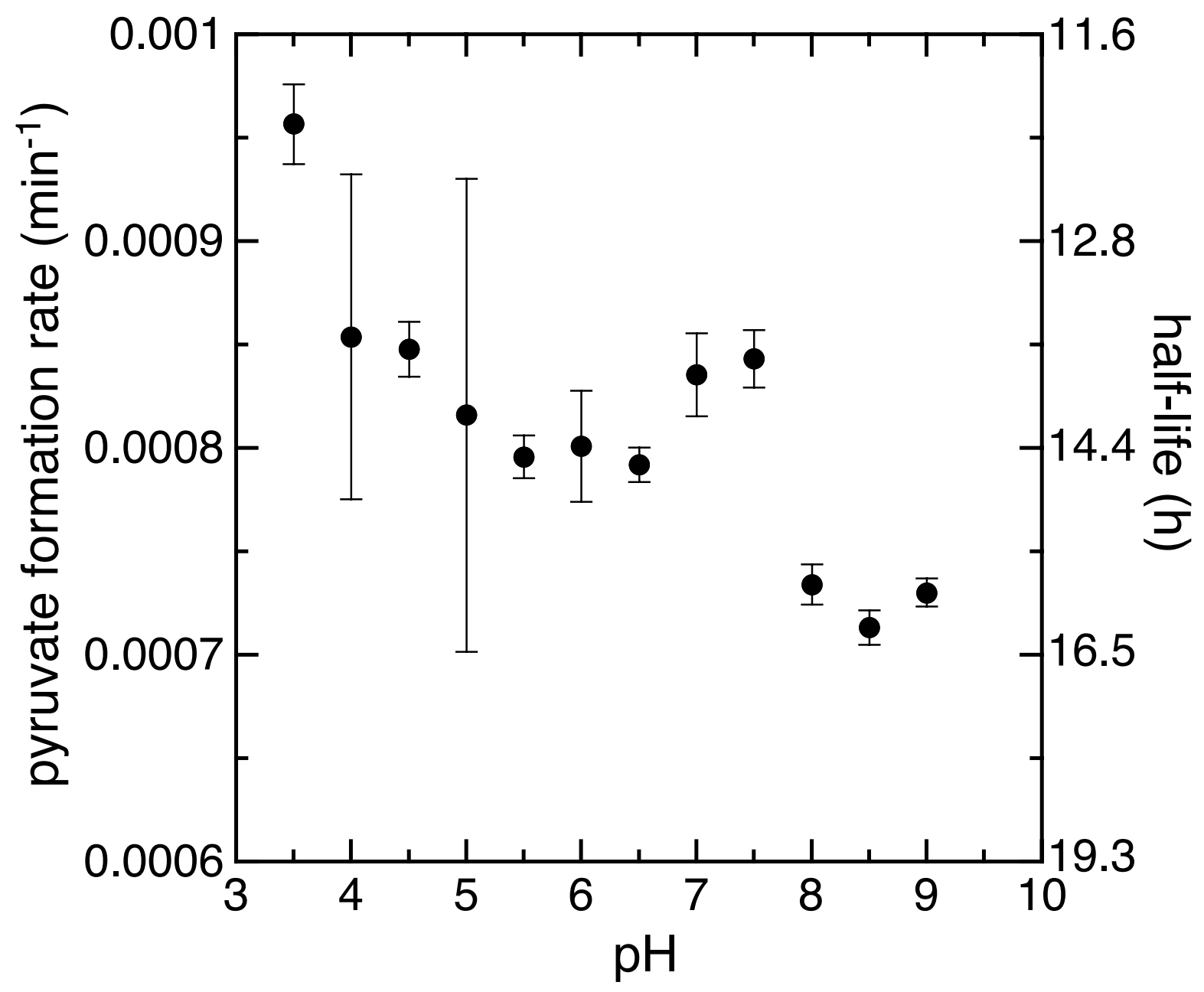

Figure S7. OAA decomposition detected by the formation of pyruvate. Rates were determined as described in Experimental procedures. Approximate half-lives are shown on the second $y$ axis. 


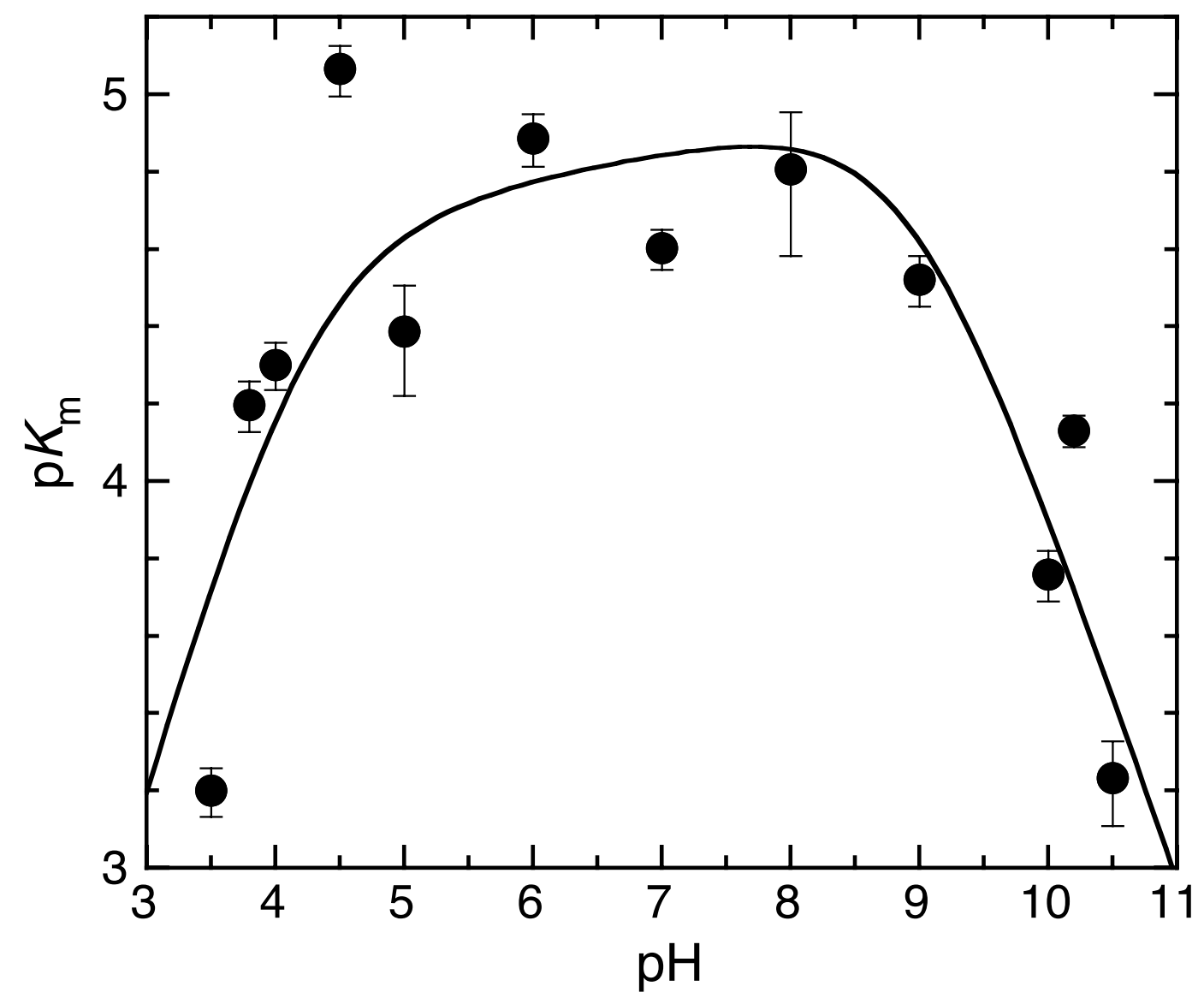

Figure S8. $\mathrm{p} K_{\mathrm{m}}$ for OAA as a function of $\mathrm{pH}$. This experiment used AaCSH6 and assay A. The line is a fit to Equation 1, using $\log y=\mathrm{p} K_{\mathrm{m}}$, which yielded $c=10100 \pm 4100, \mathrm{p} K_{1}=4.3 \pm 0.4$, and $\mathrm{p} K_{2}=8.9 \pm$ 0.3. At this concentration of $\operatorname{AcCoA}(0.15 \mathrm{mM})$ only the OAA data between $\mathrm{pH} 4.0$ and 9.5 were unambiguously saturating in $\operatorname{AcCoA}\left(>5 K_{\mathrm{m}}\right)$, but all points were included in the fit. 


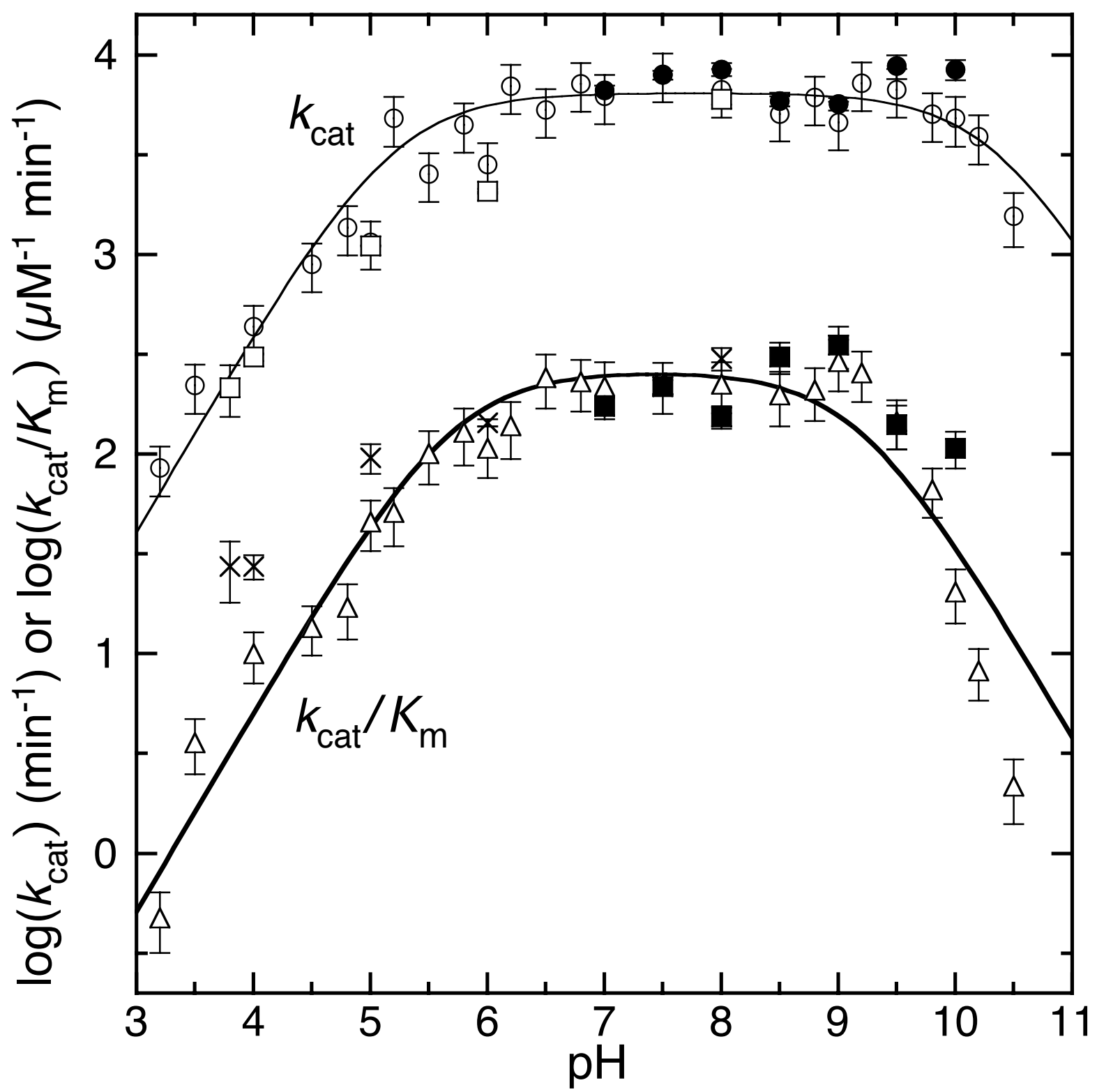

Figure S9. pH-rate profiles for $A a \mathrm{CSH} 6$, using parameters from AcCoA saturation plots for $k_{\text {cat }}$ or $k_{\text {cat }} / K_{\mathrm{m}}$ versus $\mathrm{pH}$. Each point represents a parameter from a fit to the Michaelis-Menten equation of a velocity versus $[\mathrm{AcCoA}]$ plot, performed using assay A ( $k_{\text {cat }}$, filled circles; $k_{\text {cat }} / K_{\mathrm{m}}$, filled squares) or assay B $\left(k_{\text {cat }}\right.$, open circles; $k_{\text {cal }} / K_{\mathrm{m}}$, open triangles). CitCoA $k_{\text {cat }}$ (open squares) and $k_{\text {cat }} / K_{\mathrm{m}}$ (crosses) are also shown. Solid lines are fits to Equation 1. Error bars represent the uncertainty $\left(k_{\text {cat }}\right)$ or rms uncertainty $\left(k_{\text {cal }} / K_{\mathrm{m}}\right)$ of the parameter(s) fit. Only the AcCoA data between $\mathrm{pH} 4.0$ and 9.8 were obtained under conditions clearly saturating in OAA, but all points have been included in the fits. 


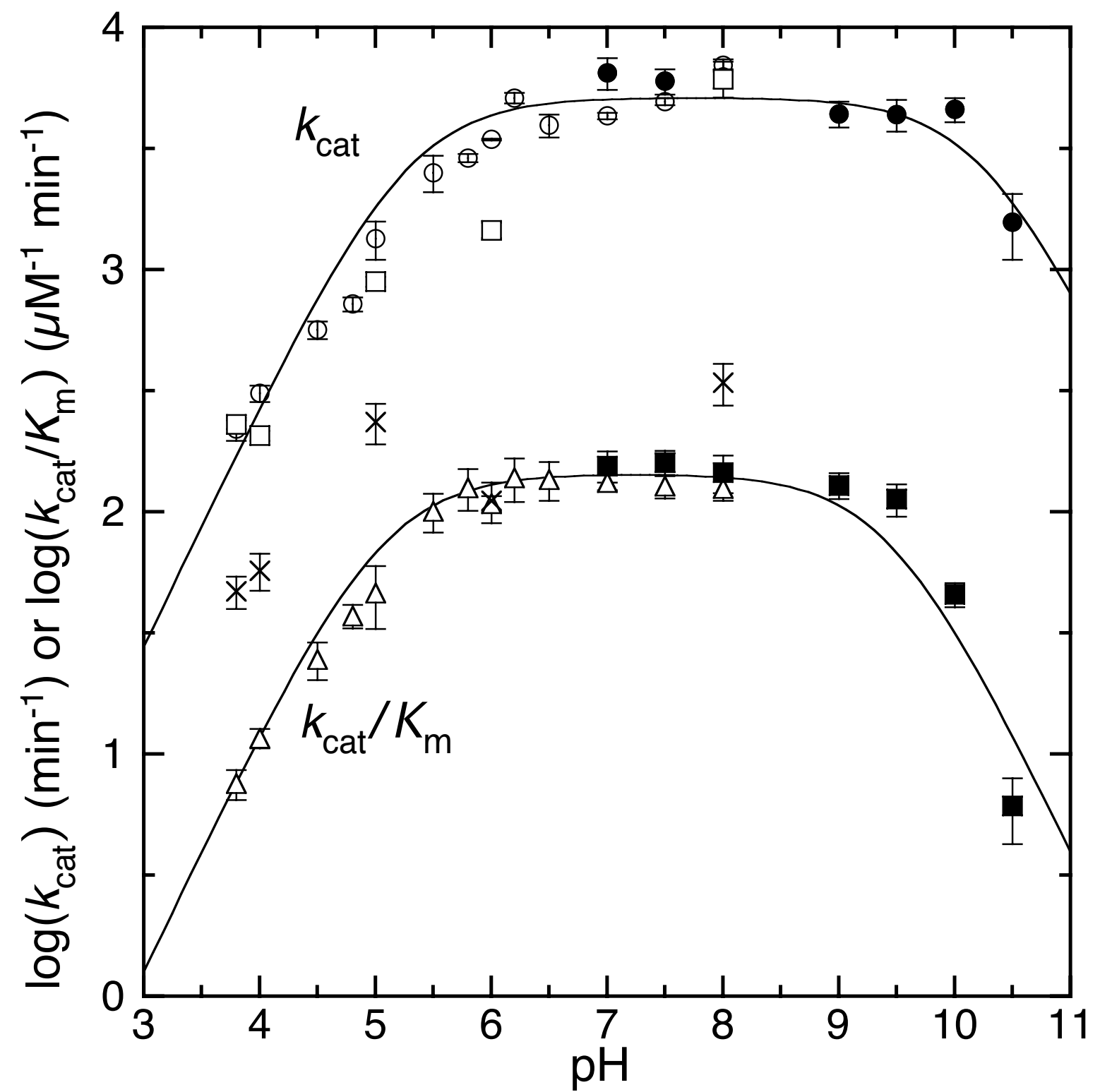

Figure S10. pH-rate profile for $A a \mathrm{CS}^{\text {intein }}$, using parameters from AcCoA saturation plots for $k_{\text {cat }}$ or $k_{\text {cat }} / K_{\mathrm{m}}$ versus $\mathrm{pH}$. Each point represents a parameter from a fit to the Michaelis-Menten equation of a velocity versus $[\mathrm{AcCoA}]$ plot, performed using assay A $\left(k_{\text {cat }}\right.$, filled circles; $k_{\text {cat }} / K_{\mathrm{m}}$, filled squares) or assay B $\left(k_{\text {cat }}\right.$, open circles; $k_{\text {cat }} / K_{\mathrm{m}}$, open triangles). CitCoA $k_{\text {cat }}$ (open squares) and $k_{\text {cat }} / K_{\mathrm{m}}$ (crosses) are also shown. Error bars represent the uncertainty $\left(k_{\text {cat }}\right)$ or rms uncertainty $\left(k_{\text {cal }} / K_{\mathrm{m}}\right)$ of the parameter(s) fit. Only the AcCoA data between $\mathrm{pH} 4.0$ and 9.8 were obtained under conditions clearly saturating in OAA, but all points have been included in the fits. Fitted $\mathrm{p} K_{\mathrm{a}}$ values are given in Table 1. 


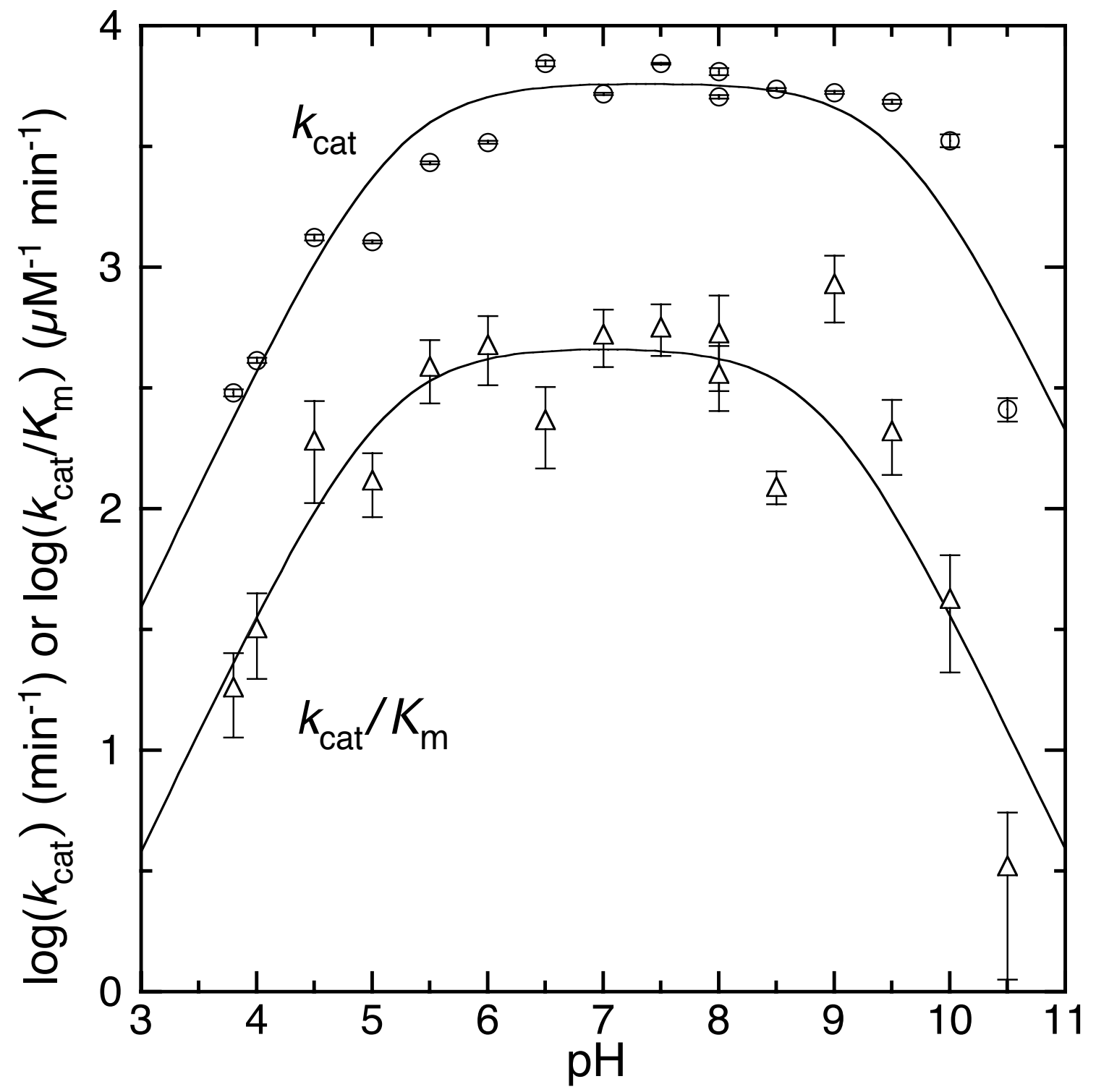

Figure S11. pH-rate profile for $A a \mathrm{CS}^{\text {intein }}$, using parameters from OAA saturation plots for $k_{\text {cat }}$ or $k_{\text {cal }} / K_{\mathrm{m}}$ versus $\mathrm{pH}$. Each point represents a parameter from a fit to the Michaelis-Menten equation of a velocity versus [OAA] plot, performed using assay B ( $k_{\mathrm{cat}}$, open circles; $k_{\mathrm{cal}} / K_{\mathrm{m}}$, open triangles). Extinction coefficients at $233 \mathrm{~nm}$ were determined at each $\mathrm{pH}>8.5$. Error bars represent the uncertainty $\left(k_{\text {cat }}\right)$ or rms uncertainty $\left(k_{\text {cat }} / K_{\mathrm{m}}\right)$ of the parameter(s) fit. Only the OAA data between $\mathrm{pH} 3.8$ and 9.0 were obtained under conditions clearly saturating in $\mathrm{AcCoA}$, but all points have been included in the fits. Fitted $\mathrm{p} K_{\mathrm{a}}$ values are given in Table 1. 

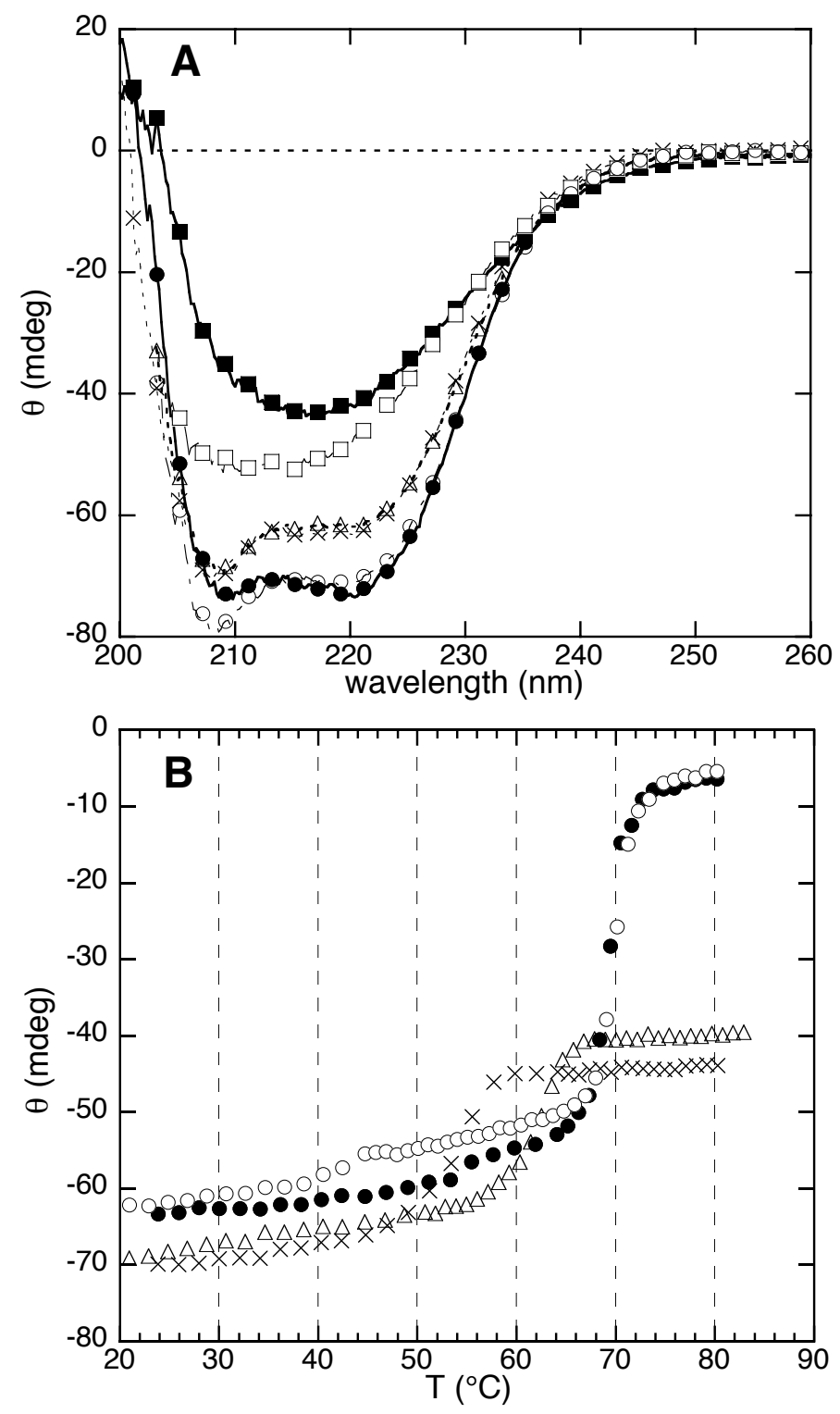

Figure S12. $A a \mathrm{CS}^{\mathrm{dye}}$ and $A a \mathrm{CSH} 6$ secondary structure. $A, \mathrm{CD}$ spectra of $A a \mathrm{CS}^{\mathrm{dye}}$ and $A a \mathrm{CSH} 6(0.43$ $\mathrm{mg} / \mathrm{mL}, 12 \mu \mathrm{M}$ subunits) at $23.5^{\circ} \mathrm{C}$ obtained at $\mathrm{pH} 3.5$ (AaCS ${ }^{\text {dye }}$, open circles; AaCSH6, filled circles) and $\mathrm{pH} 4.0\left(A a \mathrm{CS}^{\mathrm{dye}}\right.$, crosses; $A a \mathrm{CSH}$, open triangles). A spectrum obtained at $\mathrm{pH} 3.5$ and $80.0{ }^{\circ} \mathrm{C}$ is also shown ( $A a C S^{\text {dye }}$, open squares; $A a C S H 6$, filled squares). The near-UV CD region (260 - $\left.350 \mathrm{~nm}\right)$ is virtually featureless. $B, \mathrm{CD}$-detected thermal melting curves recorded at $\mathrm{pH} 3.5\left(\mathrm{AaCS} \mathrm{Cye}^{\text {, }}\right.$ crosses; AaCSH6, open triangles) and pH 4.0 ( $A a \mathrm{CS}^{\mathrm{dye}}$, filled circles; $A a \mathrm{CSH} 6$, open circles). Each point is the ellipticity at $222 \mathrm{~nm}$ after equilibration at each temperature. The average heating rate was $0.28 \pm 0.2^{\circ} \mathrm{C}$ per min. 

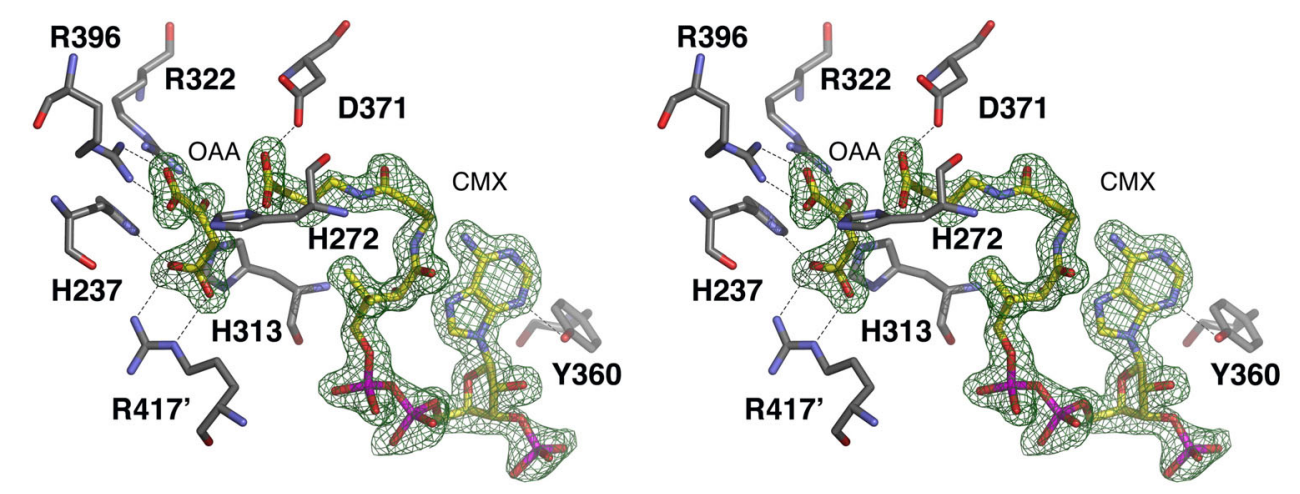

Figure S13. Divergent stereodiagram of the $\sigma \mathrm{A}$-weighted $2 F_{\mathrm{o}}-F_{\mathrm{c}}$ omit for the $\mathrm{AaCS} \cdot \mathrm{OAA} \bullet \mathrm{CMX}$ complex (PDB code 2h12). The map was calculated using the final refined structure with OAA and CMX omitted, and is contoured at $1.5 \sigma$. For clarity, electron density is illustrated only for CMX and OAA. 


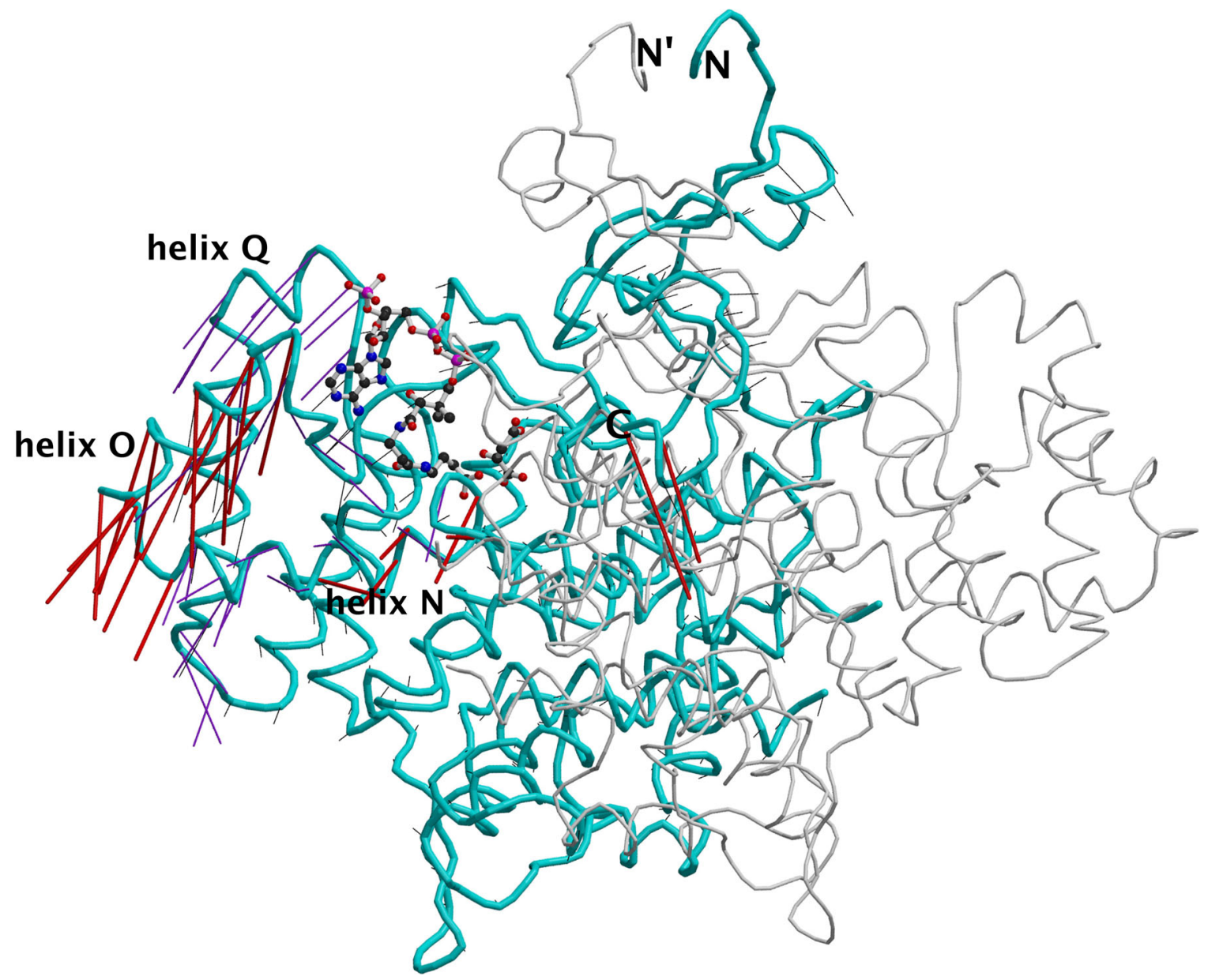

Figure S14. Rendering of motions in a dimer unit. CMX and OAA are shown bound to one $A a C S$ subunit in ball-and-stick rendering. Backbone traces for two subunits in a dimeric protomer in the "closed" AaCS•OAA•CMX structure are illustrated in thick cyan lines or thin grey lines. This dimer was superimposed on the "open" EcCS•NADH structure (PDB code $1 \mathrm{nxg}$ ), which is not shown, using DeepView (22). Straight lines are vectors that connect the $\mathrm{C} \alpha$ atom positions in the open conformation with corresponding $\mathrm{C} \alpha$ atom positions in the closed conformation: thick red lines are motions of $10 \AA$ or more, purple lines are motions of 5 - $10 \AA$, and thin black lines are motions of less than $5 \AA$. The two red lines at the center of the drawing represent a repositioning of the C-terminus. In the view shown, the long axis of the dimer is horizontal, with the N-termini at top and the core of the hexamer at bottom. 


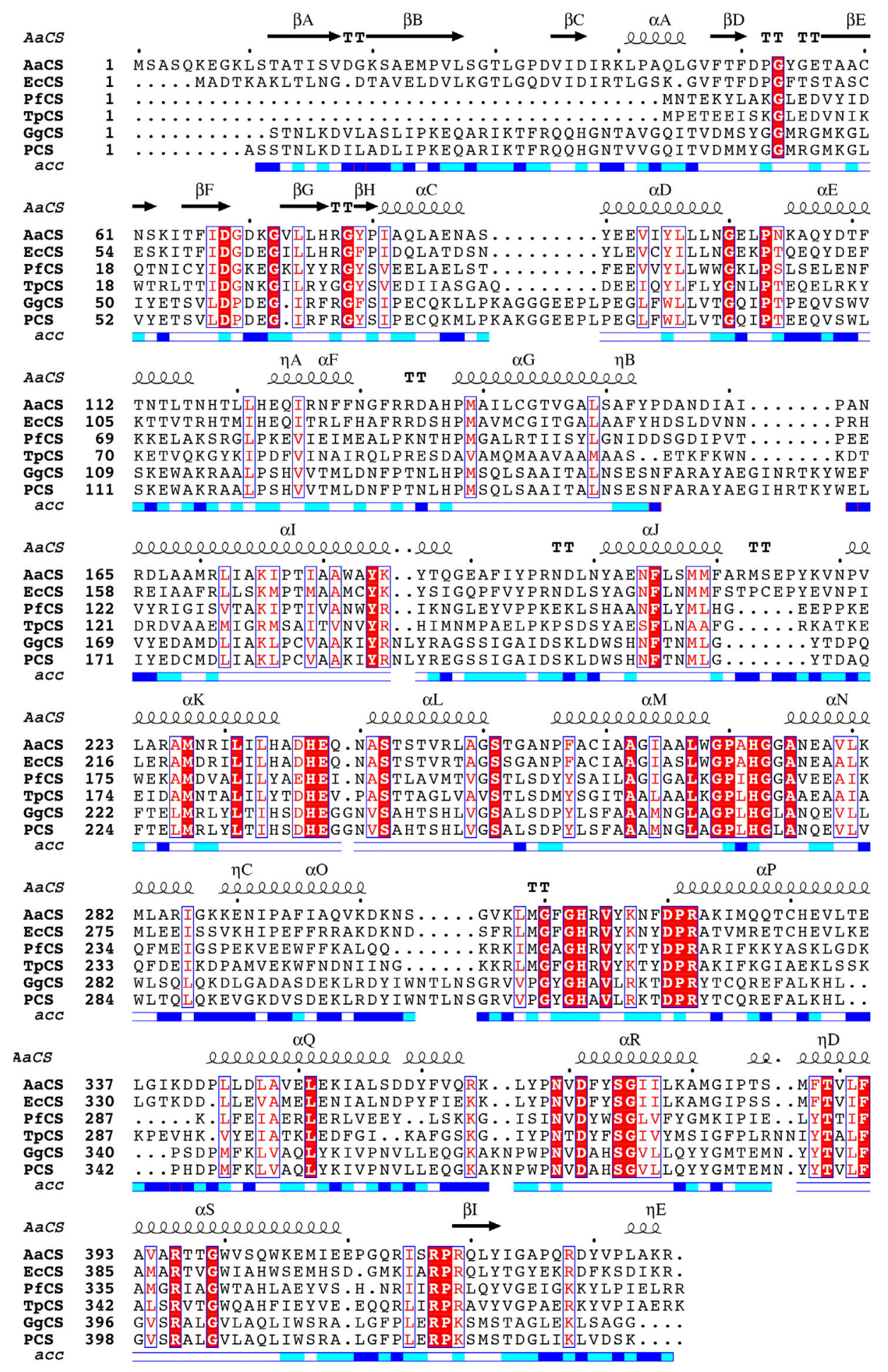

Figure S15. Structure-based sequence alignment formatted with ESPript (http://espript.ibcp.fr).

Conserved or partially conserved residues are highlighted. An inspection of crystal structures was used to edit a ClustalW (23) alignment. Secondary structure features of AaCS are shown above each sequence block. Solvent accessibilities (acc) calculated from the AaCS structure by ESPript (24) are shown below each sequence block. $A a \mathrm{CS}$ and $E c \mathrm{CS}$ are type II CSs; others are type I. Predicted leader peptides have been removed. 